\title{
A General Comparison of Two Major Families of Animal Lectins
}

\author{
二大動物レクチン家系の総合比較論 \\ Hirabayashi, J. \\ Department of Biological Chemistry, Faculty of Pharmaceutical Sciences, Teikyo University, Sagamiko, \\ Kanagawa 199-01, Japan, FAX: 81-4268-5-1606
}

Key Words: animal lectin, bricolage product, $\beta$-galactoside binding, $C$-type, S-type

\begin{abstract}
There are two major families of carbohydrate-binding proteins (lectins) in the animal kingdom: the family of calcium-dependent (C-type) lectins and the family of metal-independent $\beta$-galactoside-binding lectins (so-called S-type). As one of the approaches to an understanding of reasons for their being, a general comparison of these protein families is attempted. C-type lectins form a vast family consisting of various extracellular proteins including both lectins and lectinrelated proteins. Although they have diverse molecular architectures and functions, insofar as they are known, each molecule shows rather limited biological functions and histological distributions. Such C-type lectins can be regarded as "bricolage products", developed in the course of molecular evolution having made the best use of the carbohydraterecognition domain (CRD). On the other hand, S-type lectins form a relatively small family. At the moment, only three types of soluble metal-independent $\beta$-galactoside-binding lectins are members of this family. Though their biological roles remain elusive, recent findings of apparent homologues in some of the most primitive multicellular animals, such as sponge and nematode, strongly suggest their fundamental importance. Marked evidence that they are initially synthesized as cytoplasmic proteins implies so far unknown cytoplasmic function(s). They are possibly involved in the "essential minimum" functions for all multicellular animals in cooperation with their partner glycoconjugates, such as lactosaminoglycans. All of . these contrastive properties represent the S-type lectins as "antithesis" to the C-type lectins.
\end{abstract}

\section{A. Introduction}

One of the central questions for glycobiologists - "What is the function of glycoconjugates?"- has not been answered, partly because of practical difficulties in approaching them directly. An alternative approach of studying a group of carbohydrate-binding proteins (lectins), assuming them to be "complementary molecules" to the glycoconjugates, seems to be promising. For this purpose, a general understanding of various lectins is necessary.

The lectin which was first investigated was ricin, a
要 約

動物レクチン(糖結合タンパク質)には二つの大きなタンパ ク家系がある。一つはカルシウム要求型(C-型)レクチンの家系 で、も一つは金属イオン非要求性の $\beta$-ガラクトシド結合性レ クチン(いわゆるS-型)の家系である。動物レクチンの存在意義 を解明する一環として両レクチン家系の総合比較を試みた。C型レクチンは多種多様な細胞外タンパクの巨大集団であり、そ れらはレクチンおよびレクチン関連タンパク質からなる。C-型 レクチンの分子構築様式は多様性に富み、また知りうるかぎ り、生体での機能もさまざまである。しかし、個々の分子につ いてみると、比較的狭い生物・組織分布を示し、概して機能の 特殊化が目立つ。そのようなC-型レクチンは、分子進化の過程 で、有用な糖認識ドメイン(いわゆるCRD)を最大限に活用して できた、いわば「ブリコラージュの産物」とみなしうる。一 方、S-型レクチンの多様性はC-型レクチンと比べるとずっと小 さい。目下のところ、わずか三種の金属非要求型の可溶性 $\beta$-ガ ラクトシド結合性レクチンがこの家系を構成するにすぎない。 S-型レクチンの生体機能についてはよくわかってないが、ごく 最近、海綿や線虫といった原始的な多細胞動物でも相同なレク チンが見つかった。このことはS-型レクチンの基本的重要性を 示唆する。また、S-型レクチンは明らかに細胞質タンパクとし て合成されており、この点は本レクチンの未知なる細胞内機能 という期待をいだかせる。おそらく、S-型レクチンはラクトサ ミノグリカンのような複合糖鎖を伴侶として選びとり、ともに 多細胞動物にとって欠くことのできない要素となっているにち がいない。このようなS-型レクチンの諸性質は、C-型レクチン に対する「アンチテーゼ」として対比しうる。

\section{A. はじめに}

糖鎖生物学の中心課題である「複合糖鎖の機能解明」に取 りくむとき、我々がまっ先に直面するのは複合糖質を直接扱う うえでの実際面での難しさであろう。一方、複合糖鎖と相互作 用する糖結合タンパク質(レクチン)を「相補的分子」とみた て、レクチンの側から研究する立場もあるはずである。このた めには、いろいろなレクチンの一般的な性質について十分把握 しておく必要がある。

最初に発見されたレクチンは植物起源の毒タンパク、リシ 
toxic protein from a plant source (1), but recently much attention has been paid to animal lectins from the viewpoint of endogenous factors to distinguish complex cell surface structures through carbohydrate recognition. Thereby, they are supposed to function in various regulatory phenomena in animals: e.g., embryogenesis, morphogenesis, tumorigenesis and also defense against microorganism infection. Now animal lectins are studied as intensively and extensively as plant lectins in diverse fields.

Most animal lectins are classified into two protein families on the basis of their amino acid sequences, especially those of characteristic carbohydrate-recognition domains (CRD)(2). One is the family of lectins requiring calcium ion for their sugar-binding activity (C-type)(3). The other is the family of metal-independent $\beta$-galactoside-binding lectins which occasionally require sulfhydryl groups (so-called S-type) (4-7) [irrelevance of this terminology is described later]. An increasing amount of data on structural and functional aspects of diverse animal lectins has now been accumulated. The recent findings of a series of selectins (reviewed in 8-10) is especially noteworthy, since their carbohydrate recognition functions have been for the first time attributed clearly to an important biological phenomenon: i.e., leukocyte adhesion to inflammatory loci. These findings considerably stimulated glycoscience and glycotechnology.

At the same time, however, recent progress in molecular biological techniques has revealed a significant number of lectin-related proteins, which turned out to be homologous to the known animal lectins after sequence determination. Since this is particularly prominent for the C-type lectin family, this family is growing very rapidly. However, there remains an important question of whether or not these lectinrelated proteins actually have sugar-binding ability. Now, it seems better to step back a little from this chaotic situation because information on animal lectins is too complex and detailed to search for meaningful patterns or relationships. In this article I am attempting to compare the two major lectin families from a more general viewpoint as an approach to understanding possible reasons for their existence. Though Drickamer already attempted a similar approach (2), the situation has changed significantly during the last few years.

\section{B. Members of the C-Type Lectin Family}

Members of the C-type lectin family seem to be too diverse to be classified by a simple criterion. However, they can roughly be divided into insoluble (e.g., receptors) and soluble groups. Subsequently, each group is categorized into smaller groups. For convenience, protein architecture, biological function, distribution and other properties are used as criteria (Table I).

\section{B-1. Receptor Proteins}

ン(1)である。しかし、近年、複雑な動物細胞表面の糖鎖構造を 認識する内在性の因子として、動物レクチンが注目されるよう になった。動物レクチンは特異的な糖鎖の識別を介して、肧発 生、形態形成、腫瘍形成、さらには微生物に対する感染防御と いったさまざまな生体制御現象にかかわっていると考えられて いる。動物レクチンに関する研究は、いまや植物レクチンと同 様、幅広く、かつ集約的になされていると言ってよい。

ほとんどの動物レクチンは、アミノ酸配列に基づいて二つ のタンパク質家系に分類される。これらは、それぞれの家系に 特徴的な糖認識ドメイン(CRD)をもつ(2)。一つは糖結合活性に カルシウムイオンを要求するC-型レクチンの家系(3)で、もう一 つは金属イオンを要求しない $\beta$-ガラクトシド結合性レクチンの 家系である。後者に属するレクチンは、しばしば活性維持にス ルフヒドリル基を必要とすることから(4-7)、S-型と呼ばれるこ とが多い。この呼称が適切ではないことについては後述する。 今やいろいろな動物レクチンの構造や機能に関する知見が数多 く得られているが、中でも最近発見された一連のセレクチン 8 10に総説)は注目に值しよう。セレクチンは炎症箇所における白 血球の接着という重要な生命現象に関与するが、この分子の研 究を通して、糖鎖認識のはたす一つの役割がはじめて明確に示 されたからだ。この発見が端緒となり、糖鎖科学、糖鎖工学と いった関連分野がにわかに活気づいたのは周知のとおりであ る。

しかし、分子生物学の技術的進歩にともない、多くのレク チン様(関連)タンパク質が生じている点を見落してはならな い。これらは、構造解析により既知の動物レクチンと類似して いることが明らかになった分子であるが、この傾向はとくにC型レクチンの家系でつよい。その結果、この家系は最近たいへ ん急速な広がりを示している。だが、多くのレクチン関連タン パクについては、依然として糖結合能力の有無が確認されてい ない。動物レクチンに関するこのような混乱を含む膨大な情報 から、意味あるパターンやつながりを見いだすには、しばし各 論レベルの状態から一歩身をひくことが肝要であろう。ここで は、二つの主要動物レクチン家系の存在意義を解明すべく、よ り総合的な立場からそれらの相互比較をおこなう。同様な試み として、かつてのDrickamerによる分析が挙げられようが(2)、 ここ二、三年における状況の変化には看過しがたいものがあ る。

\section{B. C-型レクチン家系を構成するタンパク質}

C-型レクチン家系はきわめて多様なタンパク質から成り 立っており、これらを一律に分類するのはむずかしい。しか し、大まかには受容体などの不溶性タンパク群と可溶性のタン パク群に二分できる。さらに、便宜的ではあるが、それぞれの 群をタンパク構築様式や生物機能、分布様式などによって、以 下のように小さなグループに分類することができよう(表1)。

\section{B-1. 受容体タンパク群}


Table I. Classification of C-type lectins and related proteins.

\begin{tabular}{|c|c|c|c|c|}
\hline Name & Source & Sugar specificity & Other domains & Reference \\
\hline \multicolumn{5}{|l|}{$\begin{array}{l}\text { I. Receptors } \\
\text { (1) Type-I receptors } \\
\text { Selectins }\end{array}$} \\
\hline L-selectin & man, mouse & Sia+Fuc & TM, CRx2, EGF & $8,13-15$ \\
\hline E-selectin & $\operatorname{man}$ & Sia+Fuc & TM, CRx6, EGF & $9,16,17$ \\
\hline P-selectin & $\operatorname{man}$ & Sia+Fuc & TM, CRx9, EGF & $10,18,19$ \\
\hline Mannose receptor & $\operatorname{man}$ & Man, Fuc & TM, CRDx8, FN-II, CYS & $12,20-23$ \\
\hline Thrombomodulin & $\operatorname{man}$ & $?$ & TM, EGFx6 & $24-26$ \\
\hline \multicolumn{5}{|l|}{ (2) Type-II receptors } \\
\hline \multirow[t]{2}{*}{ Hepatocyte receptor } & rat, man & Gal, GalNAc & TM & $30-33$ \\
\hline & chicken & GlcNAc & $\mathrm{TM}$ & 34,35 \\
\hline Kupffer cell receptor & rat & Gal, Fuc & TM & 36,37 \\
\hline Macrophage receptor & rat, mouse & Gal, GalNAc & TM & 38,39 \\
\hline B cell IgE-receptor & man, mouse & (Gal) & $\mathrm{TM}$ & $40-43$ \\
\hline HIV-gp120 binding protein & $\operatorname{man}$ & Fuc, Man & $\mathrm{TM}$ & 49 \\
\hline $\mathrm{T}$ cell antigen Ly- 49 & mouse & $?$ & $\mathrm{TM}$ & 45 \\
\hline B cell antigen Lyb-2 & mouse & $?$ & $\mathrm{TM}$ & 46 \\
\hline \multicolumn{5}{|l|}{ NK cell antigens } \\
\hline NKG2-A,C,D & $\operatorname{man}$ & $?$ & TM & 47 \\
\hline NKR-P1 & mouse & $?$ & TM & 48 \\
\hline
\end{tabular}

\section{Sooluble Proteins}

(1) Collagenous proteins

Mannose-binding protein

Conglutinin

Pulmonary surfactant protein

(2) Proteoglycan core proteins

Cartilage proteoglycan

Fibroblast proteoglycan

\section{(3) Snake venom proteins}

Hemagglutinin

Platelet agglutinin

Coagulation factor IX/X inhibitor

Coagulating factor $X$ activating enzyme (light chain)

Phospholipase inhibitor

(4) Invertebrate body fluid Lectins

Galactose-specific lectin

Regenectin

26-kDa lectin

LPS-binding protein

\section{(5) Others}

Pancreatic stone protein

Regenerating islet protein

Tetranectin

Anti-freeze protein
Man, Fuc $>$
Man, Fuc $>$
Fuc, Man,
Gal, Fuc
?

rat, chick

man

rattlesnake

Bothrops jararaca

habu snake

Russell's viper ?

habu snake serum ?

$\begin{array}{ll}\text { CLG } & 50,51 \\ \text { CLG } & 50 \\ \text { CLG } & 52 \\ \text { CLG } & 56-58,61-63\end{array}$

GAG, HLA, CYS

EGFX2, CYS

64,65

66

$\begin{array}{lll}\text { tunicate } & \text { Gal } & 77 \\ \text { sea urchin } & \text { Gal } & 78 \\ \text { fresh fly } & \text { Gal } & 79 \\ \text { barnacle } & \text { Gal } & 82,83 \\ \text { cockroach } & \text { Sucrose } & 80 \\ & \text { Ram } & 80 \\ & \text { E. coli } \text { LPS } & 81\end{array}$

Abbreviations: TM, transmembrane domain; CR, complement regulatory domain; EGF, epidermal growth factor-like domain; CRD, C-type carbohydrate-recognition domain; CYS, Cysteine-rich domain; FN-II, fibronectin type II repeat; CLG, collagenous domain; GAG, glycosaminoglycan domain; HLA, hyaluronic acid binding domain; MP, metaloproteinase domain; DIS, disintegrin-like domain; LPS, lipopolysaccharide. 
B-1-a. Type-I Receptors (8-10, 12-29)

Type-I receptors are membrane-integrated proteins, of which $\mathrm{N}$-terminal regions are exoplasmic and $\mathrm{C}$-terminal regions are cytoplasmic (11). Their precursors may have a cleavable signal (leader) sequence. Though most receptor molecules take such orientation, only few examples have been found among C-type lectins, i.e., selectins (reviewed in 8-10) and macrophage mannose receptor (reviewed in 12). In these cases, $\mathrm{C}$-type CRDs are located in the $\mathrm{N}$-terminal region exposed on the cell surface.

There are three types of selectins; L-selectin (LECAM-1) isolated from leukocytes $(8,13-15)$, E-selectin (LECAM-2) from endothelial cells $(9,16,17)$, and P-selectin (LECAM-3) from platelets $(10,18,19)$. Though the function of the macrophage mannose receptor (removal of foreign materials via endocytosis) resembles that of type-II receptor lectins described below (20), it is unique in that it has a cleavable signal sequence and as many as eight tandemly repeated CRDs (21-23). Thrombomodulin, known as a modulator of the coagulation system, is also categorized into this group (24-26), though its sugar-binding ability has not been confirmed. It shows relatively low sequence homologies to selectins (15-20\% identities), while its molecular architecture apparently resembles those of selectins. It has extracellular EGF-like repeats (as many as 6 times) as well as an $\mathrm{N}$-terminal CRD-like structure. The former region includes important parts essential for the binding to thrombin and protein $\mathrm{C}$ (2729).

\section{B-1-b. Type-II Receptors (30-49)}

A larger proportion of membrane-integrated C-type lectins are categorized into type-II receptors. They have an $\mathrm{N}$ terminal cytoplasmic region, a hydrophobic transmembrane region and a $\mathrm{C}$-terminal exoplasmic region including CRD. They are synthesized without a cleavable signal sequence (11). Various well-known receptors; i.e., hepetic asialoglycoprotein receptor (30-32, for review see 33), chicken hepatic lectin (34, $35)$, Kupffer cell receptor $(36,37)$ and macrophage asialoglycoprotein binding protein $(38,39)$ are typical type-II receptors. They have well-defined functions: removal of glycoproteins by endocytosis and phagocytosis. Low-affinity IgE receptor (FceRII, also known as CD23, 40-43) is thought to bind an $\operatorname{IgE}$ molecule by a mechanism other than carbohydrate recognition (44). However, it was recently found to have galactose-binding activity (Ochiai, S., personal communication). Various lymphocyte-specific antigens were also found to fall into this category, though their sugar-binding activities are to be confirmed (45-48). Most of them show significant genetic polymorphism $(45,47,48)$. More recently, a placental mannose-specific protein known as an HIV gp120-binding protein became a new member of this subgroup (49).

\section{B-2. Soluble Proteins}

B-1-a. I-型受容体(8-10、12-29)

I-型受容体は、膜貫通領域をはさんでN-末端側が細胞外 に、C-末端側が細胞内に配置している膜タンパク質である (11)。翻訳後の前駆体は、のちに切断されるシグナル(リーダー) 配列をもつのが普通である。多くの他の受容体タンパク質がこ の仲間に入るが、C-型レクチンには比較的少なく、セレクチン 類(8-10に総説)とマクロファージのマンノース受容体(12に総 説）のみがこれに相当する。これらの分子のCRDはいづれもN末端側に位置し、したがって細胞表面に露出している。

セレクチンには三つのタイプがある。白血球由来のL-セレ クチン (LECAM-1)(8、13-15)、内皮細胞由来のE-セレクチン (LECAM-2)(9、16、17)、血小板などに由来するP-セレクチン (LECAM-3)(10、18、19)である。マクロファージのマンノース 受容体はエンドサイトーシスにより外来物質の除去をおこなう 点で(20)、後述するII-型受容体レクチンの仲間と似ているが、 切断されるシグナル配列をもつ点、八個ものCRDが直列につな がった構造をしているという点でユニークである(21-23)。血液 凝固系の調節因子として知られているトロンボモジュリンも構 造上はこのグループに属するが(24-26)、糖結合能については確 認されていない。とくに高い配列相同性が示されているわけで はないが(15-20\%程度)、この分子の全体的な構築様式がセレク チンと似ているのは注目に值しょう。すなわち、トロンボモ ジュリンにはN-末端部位のCRD様構造と六回のEGF様繰り返し 構造をもつ。EGF様構造中には、トロンビンやプロテインCへ の結合部位が含まれているという(27-29)。

\section{B-1-b. II-型受容体(30-49)}

膜結合性のC-型レクチンの多くはII-型受容体に属する。こ れらの分子は、中ほどの膜結合性の疎水性領域をはさみ、N-末 端部に細胞内領域、C-末端部に細胞外領域をもつ。CRDはC-末 端領域(細胞外領域)に含まれる。I-型受容体と異なり、生合成の 際に切断されるシグナル配列をもたない(11)。肝臓のアシアロ 糖タンパク受容体(30-32、33に総説)、ニワトリ肝臓レクチン (34、35)、クッパー細胞受容体(36、37)、マクロファージのアシ アロ糖タンパク受容体(38、39)など、よく知られた受容体レク チン類がこのII-型受容体に属する。これらの分子はエンドサイ トーシスやファゴサイトーシスと呼ばれる現象により、血清か ら糖タンパクを除去するという機能を担う。低親和性のIgE受容

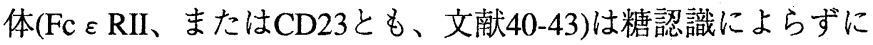
IgE分子に結合するとされているが(44)、最近、ガラクトース結 合活性をもつことも示された(落合ら、私信)。各種リンパ球に 特異的な抗原タンパクの多くが構造的にこの仲間であることが 示されているが(45-48)、糖結合活性については報告されていな い。また、これらの多くが遺伝的多型を示すという(45、47、 48)。最近では、エイズウイルスのgp120抗原に対する胎盤受容 体(マンノース特異的)が新しい仲間となっている(49)。

\section{B-2. 可溶性タンパク群}




\section{B-2-a. Collagen-like Proteins (50-63)}

This type is a chimera composed of an $\mathrm{N}$-terminal collagenous domain and a C-terminal CRD. Mannose-binding protein $(50,51)$ and conglutinin $(52)$ are supposed to activate the complement system by the classical pathway $(53,54)$. The latter molecule has a significantly long collagenous domain, and this domain is necessary for its fiunction, because truncated forms of the mannose-binding protein lacking this region failed to stimulate the complement system in vitro (55).

A major component of pulmonary surfactant designated PS-A (28-36 kDa), which potenciates the surface tensionreducing properties of surfactant lipids, is the first "lectinrelated" protein revealed by cDNA cloning $(56-58)$; its sugar-binding activity was demonstrated later $(59,60)$. Recently, the primary structure of a minor component of the surfactant designated PS-D $(43 \mathrm{kDa})$ was also determined for several species (61-63), and their striking similarities to bovine serum conglutinin (almost $70 \%$ identities) was found, while similarities to PS-A were relatively low (ca. $40 \%$ identities). This indicates that SP-Ds probably correspond to the bovine serum conglutinin.

\section{B-2-b. Proteoglycan Core Proteins (64-67)}

Proteoglycan is a very large glycoprotein consisting of various domains; e.g., a large number of attachment sites for glycosaminoglycan and hyaluronic acid, etc. So far, partial cDNA sequences for proteoglycans of rat and chicken cartilage $(64,65)$ and human fibroblast (66) have been reported. CRDs are located in their C-terminal regions. The segment encompassing C-terminal 130 residues of rat cartilage proteoglycan showed fucose- and galactose-specific lectin activity (67). The biological significance, however, of the involvement of C-type CRD in the proteoglycans remains unclear

\section{B-2-c. Snake Venom Lectins and Lectin-related Proteins} (69-76)

Crotalid and viperid snakes have a set of characteristic venomous proteins including various hydrolytic enzymes that cause complex local injury (68). The venoms also contain galactose-specific lectins which show strong hemagglutinating ability both for intact and trypsin-sensitized erythrocytes (6972). These lectins also stimulate platelet aggregation by sugar- and calcium-dependent manners $(72,73)$. We determined for the first time the complete primary structure of a rattlesnake venonf lectin and showed it is a member of the $\mathrm{C}$ type lectin family (71).

As lectin-related molecules, an inhibitor of coagulation factor $X(74)$ and an activator of coagulation factor IX/X (75) have been isolated from habu snake and viper venoms, respectively. The latter is a two-chain-composed multidomain protein. The heavy chain contains metaloprotease, disintegrin (platelet aggregation inhibitor)-like and unknown cysteine-rich domains, while the light chain consists of

\section{B-2-a.コラーゲン様タンパク質(50-63)}

マンノース結合タンパク質(50、51)、コングルチニン(52) はN-末端側にコラーゲン様構造を、C-末端側にCRDをもつキメ ラ構造をしている。コングルチニンのコラーゲン様配列はマン ノース結合タンパク質のそれより長い。これらの分子は古典経 路を介した補体系の活性化に関与すると考えられているが(53、 54)、コラーゲン様ドメインはこの機能を発揮するうえで重要で ある。マンノース結合タンパク質でこの部分を削除すると、補 体系活性化能が失われてしまう(55)。

肺サーファクタントタンパク質の主要成分であるPS-A(28$36 \mathrm{kDa})$ は、cDNAクローニングの結果、はじめてレクチン関連 タンパク質であることが示された最初の例である(56-58)。この タンパク複合体はサーファクタント脂質の表面張力を低くする ものと考えられているが、その後の実験で、PS-Aに糖結合活性 があることが確認された(59、60)。最近、サーファクタント複 合体の少量成分であるPS-D(43 kDa)の一次構造が、いくつかの 動物について決定された(61-63)。驚くべきことに、PS-Dはウシ のコングルチニンと非常によく似ていた(約70\%一致、PS-Aとの 類似性は約40\%)。構造決定されたPS-Dはウシ血清コングルチ ニンの相同物なのかもしれない。

B-2-b. プロテオグリカンコアタンパク質(64-67)

プロテオグリカンは多様なドメイン構造をした巨大糖タン パク質であり、グリコサミノグリカンやヒアルロン酸等の多く の結合部位をもつ。これまでに、ラット、およびニワトリの軟 骨(64、65)、さらにヒト繊維芽細胞由来(66)のプロテオグリカン に対する部分cDNA構造が報告されている。これらプロテオグ リカン中、CRDはC-末端に位置するが、実際にラット軟骨プロ テオグリカンのC-末端130残基を含む断片は、フコース、および ガラクトースに特異的なレクチン活性を示した(67)。しかし、 プロテオグリカンに含まれるC-型CRDの意義については明らか にされていない。

\section{B-2-C. 蛇毒レクチンおよび関連タンパク質(69-76)}

マムシ科やクサリヘビ科の蛇の毒液中には、複雑な局所性 の障害を起こす一連の毒タンパクが含まれている(68)。この中 にガラクトース特異的レクチンが見つかっており、未処理、お よびトリプシン処理した赤血球に対し、高い凝集活性を示す (69-72)。これら蛇毒レクチンは糖、およびカルシウム依存的に 血小板凝集も起こす $(72,73)$ 。筆者らは、いち早くガラガラ蛇毒 に含まれるレクチンの一次構造を決定し、これがC-型レクチン の仲間であることを示した(71)。

蛇毒由来のレクチン関連タンパク質としては、凝固系第X 因子の阻害因子(74)がハブから、第IX/X因子の活性化因子(75)が クサリヘビからそれぞれ単離されている。後者の活性化因子は 二本鎖からなる多ドメイン性タンパク質で、CRDは軽鎖を構成 する。一方の重鎖は金属プロテアーゼドメイン、ジスインテグ リン(血小板凝集阻害因子)椂ドメイン、システインに富む未知 
only a CRD. Besides venom, habu snake serum contains a kind of phospholipase inhibitor which turned out to have a Ctype lectin-like structure (76). It has not been confirmed whether or not these lectin-related proteins have sugar-binding activities. It is not known why these C-type lectins and related proteins have been found exclusively in crotalids and viperids, and never found in other poisonous snakes such as elapids (cobra) and hydrophiids (sea snake). However, the latter snakes are known to possess distinguished lethal neurotoxins, while the former do not.

\section{B-2-d. Invertebrate Body Fluid Lectins (77-84)}

C-type lectins have been found in the body fluids of various invertebrate species; i.e., tunicate (77), sea urchin (78), fly (79), cockroach $(80,81)$ and barnacle $(82,83)$. Most of them are galactose-specific, while a cockroach hemolymph protein shows specific affinity for lipopolysaccharide of Escherichia coli (81). Their subunit structures are usually simple consisting of only a CRD. However, they usually form high molecular weight polymeric structures under non-denaturing conditions. They are supposed to be substitutes for immunoglobulins and be involved in defense against bacterial infection. The lectin of sarcophaga plays an important role during metamorphosis (84).

B-2-e. Others (85-91)

Pancreatic stone protein, being present in pancreatic
のドメインからなる。毒液ではないが、ハブの血清からはC-型 レクチン様構造をしたフォスフォリパーゼ阻害因子が見つかっ ている(76)。これらレクチン関連タンパク質の糖結合活性は、 まだ確認されていない。なぜ、これらC-型レクチンとその関連 タンパク質が、もっぱらマムシ科とクサリヘビ科の蛇で見つ かって、コブラ科やウミへビ科の蛇では見つかっていないのだ ろう。後者の毒蛇はきわめて致死活性の高い神経毒を備えてい るので、そのことと関係あるかもしれない。

\section{B-2-d. 無脊椎動物体液レクチン(77-84)}

多くの無脊椎動物 [ホヤ(77)、ウニ(78)、八エ(79)、ゴキブ

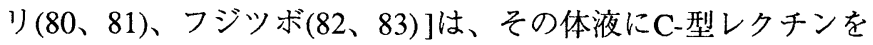
含む。これらの多くはガラクトースに特異的だが、ゴキブリの 血リンパには大腸菌のリポ多糖に特異性を示すレクチンも見い だされている(81)。無脊椎動物レクチンのサブユニットは一般 にCRDだけからなる簡単なものだが、非変性条件下では高分子 量の多量体構造をとっていることが多い。免疫グロブリンを欠 く無脊椎動物では、これらの分子が細菌などに対する感染防御 にはたらくと考えられている。八エのレクチンは生体防御だけ でなく、変態過程でも重要な役割をはたしているらしい(84)。

B-2-e. その他(85-91)

膵臓で炭酸カルシウムの結晶形成を防ぐ膵石阻害タンパク

Table II. Classification of $\beta$-galactoside-binding lectins

\begin{tabular}{|c|c|c|}
\hline Name & Source & Reference \\
\hline \multicolumn{3}{|c|}{ (1) Proto type: 14-16 kDa } \\
\hline & man (placenta, lung, muscle, spleen) & \\
\hline & marmoset (whole body) & 100 \\
\hline & rat (lung, uterus) & \\
\hline & beef (muscle) & \\
\hline & $\begin{array}{l}\text { mouse (fibroblast) } \\
\text { pig (heart) }\end{array}$ & $\begin{array}{l}102-106 \\
108\end{array}$ \\
\hline & chick (embryonic skin, adult intestine) & 109-111 \\
\hline & (embryonic muscle, adult liver) & 112 \\
\hline & frog (Xenopus skin) & 113 \\
\hline & (Rana oocyte) & 114 \\
\hline & electric eel (electric organ) & 115 \\
\hline & conger eel (mucus skin) & $116 \mathrm{a}$ \\
\hline & sponge & $116 \mathrm{~b}$ \\
\hline \multicolumn{3}{|c|}{ (2) Chimera type: $29-35 \mathrm{kDa}$} \\
\hline & man (macrophage, breast cancer) & $117-120$ \\
\hline & rat (leukemia, lung) & $121-123$ \\
\hline & mouse (fibroblast, lung, macrophage) & $124-128$ \\
\hline \multicolumn{3}{|c|}{ (3) Tandem-repeat type: $32-36 \mathrm{kDa}$} \\
\hline & $\begin{array}{l}\text { Caenorhabditis elegans } \\
\text { rat (intestine) }\end{array}$ & $\begin{array}{l}92 \\
130\end{array}$ \\
\hline
\end{tabular}


juice inhibiting growth of calcium carbonate crystals $(85,86)$, and Langerhans islet regeneration-specific protein (reg gene product) $(87,88)$ were recently proved to be the same protein. Tetranectin, a regulator of the coagulation system (89), and a type-II antifreeze protein found in smelt (90) and sea raven sera (91) are also soluble, C-type lectin-related proteins. All these molecules have a simple structure consisting of only a CRD, though their sugar binding properties have not been confirmed.

\section{Members of the S-Type Lectin Family}

Compared with C-type lectins, S-type lectins are apparently less diverse. At present, only soluble metal-independent $\beta$-galactoside-binding lectins seem to be members of the family. Based on their molecular architectures, they are subdivided into three types (92), as follows (Table II).

\section{C-1. Proto Type (14-kDa Lectin) (93-116b)}

The most common vertebrate lectins are dimeric proteins, generally called "14-kDa lectin" according to their approximate subunit sizes [14-16 $\mathrm{kDa}$ )(for references, see Table II]. "Proto" does not necessarily mean "primitive" from the viewpoint of molecular evolution. However, very recently, lectins from a sponge, Geodia cydonium, were actually isolated and proved to fall into this category (116b).

One of the unanswered questions is the occurrence of isolectins. In the case of chicken (131), there are two isolectins, called 14-kDa $(109,110)$ and 16-kDa lectins (112) according to their apparent sizes estimated by SDS-polyacrylamide gel electrophoresis. Actually, both of them have almost the same molecular weight (ca. 15,000 Da). Human 14-kDa lectin was originally isolated from placenta (132). Recently, the presence of an additional 14-kDa lectin was suggested by cDNA $(93,99)$ and gene cloning $(98,99)$. Sequence homologies between these isolectins are not so high (ca. 40-50\% identities). Their expressions appear to be regulated differently $(99,112,133)$. Some animal species belonging to the same orders (but to different class or family) also have distinct lectins (sequence identities, ca. 40\%); e.g., in the cases of frogs [Xenopus (113) and Rana (114)] and eels [electric eel (115) and conger eel (116a)]. However, such differences may reflect the rather long time period after the divergence of these species.

\section{C-2. Chimera Type (29-35-kDa Lectin) (117-128)}

Chimera-type lectins are multidomain proteins consisting of a lectin domain and other non-lectin domain(s). Mammalian lectins häing higher molecular weights $(29-35 \mathrm{kDa})$, and being called by different names such as "CBP-35" (124), "L-34" (125) or "S-Lac29" (122), are in fact chimeras composed of an $\mathrm{N}$-terminal domain resembling some heterogeneous ribonucleoprotein ( $\mathrm{hnRNP}$ ) and a C-terminal lectin domain homologous to proto-type lectins (ca. $30 \%$ identities). (85、86)とランゲルハンス島再生タンパク質(reg遺伝子産 物)(87、88)は、同一分子であることが最近示された。線溶系調 節因子であるテトラネクチン $(89) 、$ 極地海域に棲息する魚類[ワ カサギ(90)やケムシカジカ(91)]の血清に含まれる抗凍結タンパ ク質(II型)も、可溶性のC-型レクチン関連タンパク質である。こ れらの分子はいずれもCRDだけからなる比較的簡単な構造をし ているが、糖結合活性については確認されていない。

\section{S-型レクチン家系を構成するタンパク質}

以上述べてきたC-型レクチンと比較すると、S-型レクチン の多様性はずっと小さい。目下のところ、可溶性 $\beta$-ガラクトシ ド結合性レクチンの仲間だけがこの家系を構成する。これらは 分子構築様式に基づき、以下のように三つのタイプに分類でき る(92)（表II)。

$$
\text { C-1. プロト型(14 kDaレクチン)(93-116b) }
$$

もっとも一般的な $\beta$-ガラクトシド結合性レクチンは二量 体構造をとる。サブユニット分子量が14-16 kDaであることか ら、14 kDaレクチンと呼ばれることが多い（文献については表 IIを参照）。ここで、プロトとは必ずしも進化的な原型を意味 しないが、実際、海綿の一種であるGeodia cydoniumからこの夕 イプに属するレクチンが単離されており、ごく最近、構造決定 された(116b)。

このタイプには、イソレクチンに関する問題がある。たと えば、ニワトリには以前から二種のイソレクチンが存在するこ とが知られている(131)。それぞれ、SDS電気泳動上の見かけの 分子量から $14 \mathrm{kDa}$ レチン(109、110)、16 kDaレクチン(112)と 呼ばれているが、実際に一次構造から求められた分子量は、両

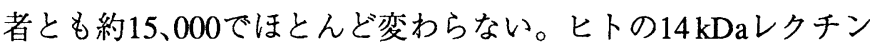
はもともと胎盤で見つかったものだが(132)、最近、新種の 14 kDaレクチンがcDNA(93、99)や遺伝子(98、99)のクローニング を通して同定されている。これら同一種におけるイソレクチン 間の配列ホモロジーはけっして高くなく、40-50\%程度の一致を 示すにすぎない。また、それらの発現も別々に調節されている ようである(99、112、133)。このほか、近縁動物種のプロト型 レクチンの間でも、低い相同性(40-50\%程度の一致)しか示さな い例がある。カエルのXenopus(113)とRana(114)のレクチン、魚 類の電気ウナギ(115)とアナゴ(116b)のレクチンなどである。し かし、こういったアミノ酸配列のちがいは、むしろ種分化後の 経過時間の長さを反映したものかもしれない。

\section{C-2. キメラ型(29-35 kDaレクチン)(117-128)}

キメラ型レクチシはレクチン、および非レクチンドメイン からなる多ドメイン性のタンパク質である。哺乳類にはCBP35(124)、L-34(125)、S-Lac29(122)など、さまざまな名まえで呼 ばれる高分子型のレクチン $(29-35 \mathrm{kDa})$ が存在するが、これらは (種が同じなら)すべて同一分子である。実際に、このレクチン は、ある種の不均一リボ核タンパク質( $(\mathrm{hnRNP})$ と相同なN-末端 ドメインとプロト型レクチンと相同な( $30 \%$ 程度の一致)C-末端 レクチンドメインからなるキメラ分子である。すでに本誌でも 
As reviewed before (128), they had also been studied independently by several researching groups as proteins having biological activity other than lectin activity, and thus, called by different names; e.g., IgE-binding protein ( $\varepsilon \mathrm{BP}, 121)$, activated macrophage antigen (Mac-2, 126), and non-integrin family laminin-binding protein (127). They turned out to be the same protein and actually to have $\beta$-galactoside-binding activity. So far, these chimera-type lectins have been found only in mammals.

C-3. Tandem-repeat Type (Nematode 32-kDa Lectin) (92, $129,130)$

This type was identified for the first time in a $32-\mathrm{kDa}$ galactoside-binding protein isolated from Caenorhabditis elegans (92). This protein is composed of two tandemly repeated lectin domains, each showing ca. $25 \%$ sequence identities to vertebrate $14-\mathrm{kDa}$ lectins. More recently, a rat intestinal 36-kDa lectin also turned out to be a tandem-repeat type (130). Apparently, tandem repeat structures are the result of gene duplication(s). Such a repeat structure has also been found in the $\mathrm{C}$-type lectin family; i.e., macrophage mannose receptor (12).

\section{Comparison of the Two Lectin Families}

\section{D-1. Structural Characteristics in Relation to Localization}

All of the C-type lectins and structurally related proteins including receptors have primary structures typical to extracellular proteins or membrane-anchored proteins. Their nascent peptides have either a cleavable N-terminal signal sequence or a hydrophobic sequence required for integration into the membrane. Many of them are glycosylated, and all of them have stable intramolecular disulfide bonds under extracellular (oxidizing) conditions. The presence of two highly conserved disulfide bonds is one of the best proofs of their assignment to $\mathrm{C}$-type lectins $(2,3)$.

In contrast, $S$-type $\beta$-galactoside-binding lectins have inherent characteristics of cytoplasmic proteins (5-7). Since no other lectins including plant ones show such properties except for discoidin I (134), this is a remarkable feature, and thus, worth restating; that is, i) they have no hydrophobic signal sequence; ii) they are not glycosylated even if they have a potential glycosylation signal; iii) they have no disulfide bond even if multiple cysteine residues are present; iv) their $\mathrm{N}$ terminal amino groups are acetylated, as far as examined. All these properties are typical to cytoplasmic proteins.

If reactive cysteine residues exist, undesirable disulfide bond(s) are likely to be formed when the lectin is left under oxidizing (extracellular) conditions. Indeed, most mammalian and chicken 14-kDa lectins were found to undergo inactivation in the absence of a thiol-reducing reagent $(5-7,135,136)$. This is the reason why $\beta$-galactoside-binding lectins were called "S-type" (2), because sulfhydryl groups were thought to be es-
触れたように(128)、これらのタンパクは複数の独立した研究グ ループによって、非レクチンタンパク質として調べられていた というユニークな経歴をもつ。すなわち、IgE結合タンパク質 ( $\varepsilon$ BP、121)、活性化マクロファージ特異抗原 $($ Mac2、126)、非 インテグリン性ラミニン結合タンパク質(127)としてである。し かし、クローニングの結果、これらはやはり、同一種であれば 同一なタンパク分子であることが判明し、また、 $\beta$-ガラクトシ ド結合活性についてものちほど確認された。このキメラ型レク チンは現在のところ、哺乳類でしか見つかっていない。

C-3. 直列反復型(線虫32 kDaレクチン)(92、129、130)

この型のレクチンは、線虫、Caenorhabditis elegansではじ めて見つかった(92)。線虫の $32 \mathrm{kDa}$ ガラクトシド結合性タンパ クは、脊椎動物の $14 \mathrm{kDa}$ レクチンと相同なレクチンドメイン(約 $25 \%$ 一致)が二回繰り返した構造をとっている。この型はラット

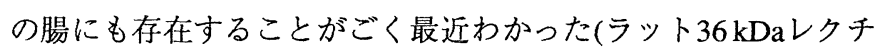
ン) (130)。直列反復型が遺伝子重複の産物であることはまちが いないが、そのような例はマクロファージのマンノース受容体 (12)のようにC-型レクチンの中にも見いだせる。

\section{D. ニ大レクチン家系の比較}

\section{D-1. 構造的特徵と局在}

すべてのC-型レクチンとその関連タンパク質は、受容体分 子であれ可溶性分子であれ、細胞外夕ンパク質に典型的な一次 構造の特徵を示す。言い換えれば、それらは翻訳後切断される シグナル配列、もしくは細胞膜貫通に必要な疎水性領域をも つ。このため、多くのC-型レクチンには糖鎖が付加されてお り、すべてのC-型レクチンが酸化的(細胞外)条件下では安定な ジスルフィド結合を形成する。C-型レクチンをもっとも特徽づ ける構造が、進化過程でつよく保存された二対の分子内ジスル フィド結合であることが想起されよう $(2 、 3) 。$

これに対し、S-型である $\beta$-ガラクトシド結合性レクチンは 細胞質タンパクとしての属性を備えている(5-7)。このような性 質はディスコイジンI(134)にも共通するが、植物起源のものを含 め、ほとんどのレクチンとは一線を画すものなので、詳しく述 ベることにする。第一に、 $\beta$-ガラクトシド結合性レクチンは疎 水性のシグナル配列をもたない。第二に、糖付加のシグナルが ある場合でも、糖鎖の付加は起こらない。第三に、システイン 残基は遊離状態(スルフヒドリル基)で存在し、ジスルフィド結 合を形成しない。第四に、アミノ末端は調べられたかぎりアセ チル化されている。こういった特徴はすべて細胞質タンパクを 特徵づける性質である。

反応性の高いシステイン残基があると、酸化的(細胞外的) な条件では好ましくないジスルフィド結合ができるかもしれな い。実際、ほとんどの14 kDaレクチン(哺乳類やニワトリ)はチ オール性還元郕がないと失活してしまう(5-7、135、136)。スル フヒドリル基が糖結合活性に必要であるとの憶測から「S-型」 
sential for sugar-binding. However, this terminology does not seem truly relevant from present knowledge. Actually, many mammalian 14-kDa lectins have some reactive cysteine residues especially in the $\mathrm{N}$-terminal (Cys2) and C-terminal regions (Cys130) (101). These two turned out to form an intrachain disulfide bond under oxidizing conditions (137). This causes significant confirmational change of the proteins resulting in substantial loss of sugar-binding activity $(135,136)$. However, these cysteine residues are not conserved in other subfamilies. Mammalian 29-35-kDa lectins have only a single cysteine residue (corresponding to Cys60 of human $14-\mathrm{kDa}$ lectin). But this cysteine residue was hardly reactive (138). Moreover, the nematode $32-\mathrm{kDa}$ lectin completely lacks cysteine (92). In the cases of mammalian $14-\mathrm{kDa}$ lectins, it turned out that modification of cysteine residue(s) with monoiodoacetamide substantially protected the lectins against oxidative inactivation (135). Recent site-directed mutagenesis analysis showed that none of six cysteine residues of human $14-\mathrm{kDa}$ lectin is necessary for the sugar-binding function (136). All these lines of evidence rule out the essential role of cysteine residues.

One of the basic problems of $\beta$-galactoside-binding lectins, however, is that no convincing explanation for the mechanism of their extracellular transport has been given. This suggests the presence of an unknown secretion mechanism which does not depend on hydrophobic signal sequence other than a classical signal theory applied to C-type lectins. Cooper et al. (139), and Harrison and Wilson (141) independently reported that, during murine myoblast fusion, the 14$\mathrm{kDa}$ lectin molecules are initially distributed diffusely within the cell, and as the fusion progresses, they become concentrated in peripheral regions of the cytosol, then are evaginated to form vesicles, and finally secreted to extracellular space. Based on this observation, Cooper et al. proposed the term "ectocytosis" (139), though it apparently resembles a "degranulation/exocytosis" process previously observed in some granular proteins (141). Though the biological significance of ectocytosis or degranulation/ exocytosis is not clear, this mechanism may be necessary for preventing lectins from interfering with sugar processing events occurring in the endoplasmic reticulum, or advantageous when secretion of abundant lectins in a short time is required.

In contrast to C-type lectins which have typical extracellular domains, of which CRDs are always located in extracellular spaces, S-type lectins are originally cytoplasmic proteins and should have so far unknown cytoplasmic function(s). Then, they seem to be externalized by a non-classical pathway and play some extracellular roles including the interaction with ligand glycoconjugates.

\section{D-2. Sugar-binding Properties}

$\mathrm{C}$-Type lectins require of the order of $1 \mathrm{mM}$ calcium ion
レクチンという呼称が生まれるのだが、この呼び方は現在の知 識からすると適当とは言えない。このことを以下に説明しょ う。たしかに、多くの哺乳動物の $14 \mathrm{kDa}$ レクチンは、反応性に 富んだシステイン残基を $\mathrm{N}$-末端部(Cys2)とC-末端部(Cys130)に もっている(101)。これらシステイン残基は、酸化的な条件では 分子内ジスルフィド結合を形成する(137)。さらに、このことが 引き金になって、レクチン分子に重大なコンフォメーション変 化が起こり、その結果、糖結合活性が失われる(いわゆる酸化的 失活、135、136)。しかし、これらのシステイン残基は、他の $\beta$-ガラクトシド結合性レクチンでは必ずしも保たれていない。 たとえば、哺乳類のキメラ型29-35kDaレクチンにはシステイン が一残基あるだけで(ヒト14 kDaレクチンのCys60に相当)、しか もほとんど反応性がない(138)。先の線虫レクチンにいたっては

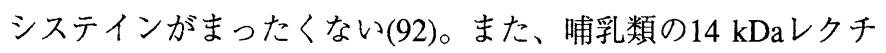
ンのシステイン残基をモノヨードアセタミドで修飾すると、効 果的に酸化的失活を防げる(135)。最近、われわれはヒト $14 \mathrm{kDa}$ レクチンについて部位特異的変異をおこなったが、このレクチ ンが6個もつシステイン残基は、いずれも糖結合機能に重要では なかった(136)。これらの観察結果から、システイン残基の重要 性は完全に否定される。

$\beta$-ガラクトシド結合性レクチンにおける重要な一つの未 解決問題は、細胞外輸送に関する問題である。このレクチンが 特定のシグナル配列をもたないのに分泌されているからだ。C型レクチンとは異なり、 $\beta$-ガラクトシド結合性レクチンには従 来のシグナル理論では説明できない別の分泌機構があるらし い。Cooperら(139)、およびHarrisonとWilson(141)は、マウスの 筋芽細胞の融合期における $14 \mathrm{kDa}$ レクチンの局在ついて、独立 に研究をおこなった。彼らの報告によると、レクチン分子は最 初、細胞質に散在しているが、融合期になると細胞質内の周辺 に集まるようになり、やがて出芽物を形成し、最後には培地へ と放出されるという。この観察にもとづいて、Cooperらは「エ クトサイトーシス」という分泌機構を提唱している(139)。おも しろいことに、この現象は顆粒球タンパクなどで知られている 「脱顆粒/エキソサイトーシス」という現象と似ている(141)。 このエクトサイトーシス(脱顆粒/エキソサイトーシス)の生理 的意義はよくわかっていないが、小包体内での糖鎖のプロセッ シングを妨げずにすむ、必要なときに多量のレクチンタンパク を一度に分泌することができる、などの理由が考えられよう。

以上まとめると、典型的な細胞外タンパク質で、いつも CRDを細胞外に配備しているC-型レクチンとは対照的に、S-型 レクチンは基本的に細胞質タンパクとしての属性を備えてい る。このことは、S-型レクチンが細胞内で未知の機能を発揮し ている可能性を示唆する。一方、S-型レクチンは古典的な分泌 過程によらない独自の機構で細胞外へと輸送され、複合糖鎖と の相互作用を含んだ細胞外機能にたずさわるらしい。

\section{D-2． 糖結合に関する性質}

C-型レクチンは、一般に活性発現に $1 \mathrm{mM}$ 程度のカルシウ 
to express their activity. Recently, three-dimensional structures of the rat mannose-binding protein in its free (142) and sugar-complexed forms (143) were reported. Two or three calcium ions are bound to one CRD, and one of them was found to coordinate amino acid residues involved in the sugar binding. Since calcium binding is reversible, this property has been often utilized for purification. However, this should also be of biological importance because lectin activity can be regulated by the change in calcium ion concentration. A recent study on the biosynthesis of hepatic asialoglycoprotein receptor suggested that calcium ion is also required for the translocation from endoplasmic reticulum to Golgi apparatus (144).

Lee $e t$ al. systematically analyzed sugar-binding properties of C-type lectins, $\mathrm{N}$-acetylglucosamine-specific chicken hepatic lectin (145), galactose-specific rat hepatic lectin (146) and rat serum mannose-binding protein (147) using a series of competitive oligosaccharides. These $\mathrm{C}$-type lectins showed several common properties in spite of their different sugar specificities; that is, i) they recognize only non-reducing terminal monosaccharide moieties; ii) 3- and 4-hydroxyl groups of the target monosaccharide are important for recognition; iii) they show extremely high affinity for branched sugar chains (clustering effect).

The second point explains well why most mannose-specific lectins have affinity for $\mathrm{N}$-acetylglucosamine besides mannose, because the substituting group at $\mathrm{C}-2$ position is not critical: This also explains the first point, because hydroxyl groups of C-3 and C-4 positions are often used for the formation of glycosidic bond in sugar chains. The third clustering effect seems the most important characteristics of C-type lectins. In fact, they show extremely enhanced affinity for bi- and triantenary sugar chains, while that for a uniantenary chain is rather low ( $\mathrm{Ki}$ of the order of $1 \mathrm{mM}$ ). This suggests that these C-type lectins adopt highly organized oligomeric structures. The $\mathrm{X}$-ray crystallographic analysis revealed that two CRD of rat mannose-binding protein binds two non-reducing end mannose residues of the branches of a biantenary chain which extend in opposite directions (143). Thus, recognition by these C-type lectins can be said to be "superficial" (only terminal recognition) but "tight" (clustering effect).

A different mode had been expected for selectins, since they appear to recognize both fucose and sialic acid present in Sia-Le ${ }^{\mathrm{X}}$ or Sia-Le ${ }^{\mathrm{a}}$ structure (148-150). However, systematic analysis of E-selectin using monoclonal antibodies and mutant lectins showed that these two saccharide moieties are located closely enough to be recognized by a relatively small part of the lectin (151). There is also evidence that $\mathrm{L}$-selectin requires sulphation of the ligand (152). Thus, true structures of selectin ligands remain to be elucidated. However, it seems that the involvement of an acidic group in the ligand recognition confuses the lectin researchers unnecessarily.
ムイオンを必要とする。最近、ラットのマンノース結合性タン パク質の遊離型(142)、および糖鎖との複合体(143)の三次構造が 報告されたが、カルシウムイオンはCRDあたり二ないし三分子 結合し、そのうちの一個が糖結合にかかわるアミノ酸残基の配 向性を規定していることがわかった。カルシウムイオンとの結 合は可逆的なため、精製などに際しても便利だが、実用面ばか りでなく、生物機能のうえでも重要にちがいない。たとえば、 カルシウムイオンの濃度変化による活性調節も可能であろう。 肝レクチンの生合成に関する最近の知見では、カルシウムイオ ンは小包体からゴルジ体への輸送の際にも必要であるという (144)。

Leeらは、さまざまなオリゴ糖を阻害剤としてもちい、い ろいろなC-型レクチンの糖結合に関する系統的な解析をおこ なった。すなわち、N-アセチルグルコサミンに特異的なニワト リ肝レクチン(145)、ガラクトースに特異的なラット肝レクチン (146)、そしてラットの血清型マンノース結合性レクチン(147)に ついて調べたところ、これら一連のC-型レクチンが、糖特異性 にかかわらず、共通の結合上の性質をもつことがわかった。第 一に、いずれのレクチンも非還元末端の単糖を認識する。第二 に、この認識に重要なのは、標的単糖の3位、および4位であ る。第三に、分岐型糖鎖に対してとくに高い親和性を示す(クラ ス夕一効果)。

第二の点は、なぜ多くのマンノース特異的レクチンがN-ア セチルグルコサミンにも高い親和性を示すのかをうまく説明で きる。C-2位の置換基や立体は重要でないのだ。このことは、ま た第一の点ともつじつまがあう。なぜなら、多くの場合、C-3、 C-4位の水酸基はグリコシド結合に使われているため、必然的に 末端認識になるためである。第三のクラス夕一効果は、C-型レ クチンの糖結合モードを記述するうえでもっとも大切だ。実際 に、C-型レクチンは一本鎖型糖鎖に対しては $1 \mathrm{mM}$ 程度のKi值し か示さないが、二本鎖、三本鎖型と分岐がふえると親和力は相 乗的に増加していく。このことは、C-型レクチンが高度に組織 化されたオリゴマー構造をとっていることを物語る。先のラッ トのマンノース結合性レクチンのX-線結晶解析では、二つの CRDは正反対方向にのびた二本の糖鎖の非還元末端マンノース をうまくとらえていた(143)。よって、C-型レクチンの糖結合様 式を要約するなら、「広く浅く、しかし、総じてつよく」とな ろうか。

セレクチンはSia-Lex、およびSia-Lea糖鎖構造のフコースと シアル酸の両方を認識するため(148-150)、若干異なる結合モー ドを考えなければならない。しかし、E-セレクチンについて単 クローン抗体や変異体セレクチンをもちいた系統的な解析によ ると、フコースとシアル酸双方は、セレクチンの比較的せまい 部分による認識が可能らしい(151)。最近、L-セレクチンの認識 には硫酸化が重要との知見もあり(152)、七レクチンのリガンド 検索についてはしばらく予断を許さない状況である。ただ、特 異性の問題に酸性基がからんだことが、必要以上にこの種の仕 事に混乱を招いているようにも思える。 
Binding modes of S-type lectins revealed by several independent groups (153-158) are as follows: i) both protoand chimera-type lectins recognize disaccharide units such as lactosamine; ii) in this case, the 4- and 6-hydroxyl groups of galactose and the 3-hydroxyl group of $\beta$-linked glucosamine are important; iii) little clustering effect is observed even when branched sugars are ligands. Sialylation of nonreducing terminal galactose residue by $\alpha 2,6$ linkage results in drastic reduction of the binding activity, while sialylation by $\alpha 2,3$ linkage has little effect $(153,154)$. Therefore, the sugar-binding function of S-type lectins might be controlled via sialylation events by the actions of different sialytransferases.

The lectins also show affinity for Galß1-3GlcNAc with a binding strength almost comparable to that for lactosamine (Galß1-4GlcNAc). Model building of these isomers indicates that all three hydroxyl groups discussed above can be located in almost the same positions by rotating the glycosidic bond. Therefore, it is the spacial arrangement made of the three hydroxyl groups that are important for recognition. It is possible that a similar mechanism is adopted in the case of Gal $\beta 1-3(4)$ GlcNAc $\alpha 2,3$-sialyltransferase (159), which transfers sialic acid to either Gal $\beta 1$ 3GlcNAc or Galß-4GlcNAc with comparable efficiency.

Though sugar-binding specificities of proto-type and chimera-type lectins are similar, they are not the same; for example, the rat $29-\mathrm{kDa}$ lectin shows 100 -fold higher affinity than the rat $14-\mathrm{kDa}$ lectin for a lactosamine derivative, GalNAc $\beta 1-3$ (Fuc $\alpha 1-2)$ Gal $\beta 1-4$ GlcNAc $(153,154)$. Therefore, their endogeneous ligands and their functions should be different. Polylactosamine has been nominated as a possible endogenous ligand of $\beta$-galactoside-binding lectins $(158,160-164)$. This was first demonstrated by Oda and Kasai by the combination of photoaffinity labeling and endo- $\beta$ galactosidase digestion (165). A number of experiments suggested that laminin which contains polylactosamine structure is one of the possible endogeneous receptors. In fact, proteins purified from human melanoma and thioglycolate-elicited mouse macrophage by an immobilized laminin column proved to be human $14-\mathrm{kDa}$ lectin (162) or mouse chimeratype $35-\mathrm{kDa}$ lectin (127), respectively. Tissue-type fibronectin is also a candidate receptor (158). However, it is difficult to obtain conclusive evidence by such experiments done in non-physiological conditions.

As discussed above, there are distinct differences in sugar-binding properties between C-type and S-type lectins; that is, i) calcium dependency; ii) recognition unit (terminal or internal; and iii) significance of clustering effect.

\section{D-3. Structure-function Relationship}

A clear result on structure-function relationship for a C-type lectin was obtained by a Drickamer's group $(166,167)$
一方、S-型レクチンの糖結合モードについては、多くの独 立したグループによる一致した結果が得られている(153-158)。 第一に、プロト型もキメラ型のレクチンもラクトサミンのよう な二糖構造を認識単位とする。第二に、この認識に重要なのは ガラクトースの4-位と6-位の水酸基、および $\beta$ 結合でつながっ たグルコサミンの3-位の水酸基である。第三に、分岐型糖鎖に 対するクラスター効果はほとんど認められない。もし、非還元 末端のガラクトースが $\alpha 2-6$ 結合によってシアル化されると結合 活性が大きく低下してしまうが、 $\alpha 2-3$ 結合ではほとんど影響が ない(153,154)。したがって、S-型レクチンの糖結合活性が、異 なるシアル酸転移酵素による修飾を介して調節されている可能 性がある。

\section{S-型レクチンはラクトサミン (Gal $\beta$ 1-4GlcNAc)のほかに、} その異性体である Gal $\beta 1$-3GlcNAcにも同等の親和性を示す。グ リコシド結合を回転させ、これらの分子模型を組んでみると、 先に述べた三つの水酸基はすべてほほ同じ位置にくることがわ かる。したがって、S-型レクチンの認識に重要なのは、これら 三つの水酸基の空間的な配置となる。同様な例として、Gal $\beta 1$ 3(4)GlcNAc $\alpha$ 2-3シアル酸転移酵素(159)が挙げられるかもしれ ない。この酵素は、Gal $\beta$ 1-3GlcNAcとGal $\beta$ 1-4GlcNAc双方にシ アル酸を転移するからだ。

プロト型とキメラ型レクチンの特異性はまったく同じでは

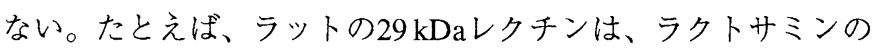
一誘導体であるGalNAc $\beta$ 1-3(Fuc $\alpha$ 1-2)Gal-GlcNAcに対し、同 ビラット由来の $14 \mathrm{kDa} レ$ ンンより百倍も高い親和性を示す (153、154)。このことは、これらのレクチンに対する内在性リ ガンドが実際は異なり、よって機能も異なっていることを示唆 する。 $\beta$-ガラクトシド結合性レクチンの内在性リガンドは、以 前からポリラクトサミン型の糖鎖だと言われている(158、160164)。これは、光標識架橋とエンド $\beta$ ガラクトシダーゼをもち いた小田と笠井の実験によってはじめて示された(165)。また、 多くの実験結果から、レクチンのレセプターとしてポリラクト サミン構造をもったラミニンが候補に挙げられている。事実、 ヒト黒色腫細胞や、チオグリコール酸で刺激したマウスマママロ ファージからラミニン固定化カラムをもちいて精製されたタン

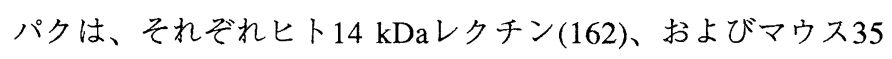
$\mathrm{kDa}$ レタチン(127)であった。組織型のフィブロネクチンもポリ ラクトサミン構造をもつため、レセプター候補となろう(158)。 しかし、これらの実験は、いずれも生理的に起こっている現象 を忠実に反映しているわけではなく、論証の決定打とはならな w。

以上議論してきたように、C-型レクチンとS-型レクチンの 糖結合特性には根本的なちがいが認められる。それは、カルシ ウムに対する依存性、認識糖鎖の単位(末端のみか内部も含むの) か)、そしてクラスター効果に扔ける差異としてとらえられる。

\section{D-3. 構造一機能相関}

C-型レクチンの構造一機能相関の問題については、ごく最 
very recently. They performed X-ray analysis of the CRD of the rat mannose-binding protein complexed with an Asnlinked biantenary sugar chain (143). The results were: i) amino acid residues involved in the sugar binding are located in the C-terminal region encompassing 25 residues, ii) two "acid-amide" pairs, Glu185/Asn187 and Glu193/Asn205, recognize the 3- and 4-hydroxyl groups of mannose, respectively, by cooperative hydrogen bonding, iii) these hydrogen bonds are strictly coordinated by the presence of one calcium ion. They found that one of the pairs, Glu185/Asn187, is critical in the sugar-specificity determination by superimposing various saccharide molecules other than mannose on a computer screen. Substitution by recombinant DNA technique of the sequence "Glu-Pro-Asn", a characteristic motif of mannosespecific lectins, with "Gln-Pro-Asp", that of galactose-specific lectins (see Fig. 1), resulted in the change of sugar specificity; i.e., a mannose-binding protein became galactose-specific. This mutant protein had lost a half of its original affinity for mannose (166).

In comparison with C-type lectins, structure-function studies on S-type lectins have advanced less. However, comparison of primary sequences of a number of proteins from diverse origins left a rather limited number of conservative residues. Their roles have been analyzed either by site-directed mutagenesis (136) or by deletion analysis (168). We constructed a series of mutants of human 14-kDa lectin, focusing on conservative hydrophilic residues, because assumed binding sites of many carbohydrate-binidng proteins are mainly formed by hydrophilic residues $(143,169)$. Hydropathy analysis of S-type lectin CRDs revealed that the central region (residues $30-90$ ) is particularly hydrophilic. In addition, most of the conservative residues including many hydrophilic ones are located in the central region, and are encoded by a single exon $(98,99,106,111,123)$. These observations suggest that this region plays a central role in the carbohydrate recognition (shaded in Fig. 2). Actually, substitutions of a series of the conserved hydrophilic residues (His44, Asn46, Arg48, Asn61, Glu71 and Arg73) led to an almost complete loss of the binding ability, while substitutions of hydrophilic residues either less conservative (Lys63) or located in the C-terminal region (Arg111 and Asp125) had little effect on the activity $(136,170)$. On the other hand, both terminal regions seem to be necessary for correct folding, because mutant proteins of the bovine $14-\mathrm{kDa}$ lectin lacking $\mathrm{N}$ terminal or $\mathrm{C}$-terminal 10 residues were found to be inactive (168). In this context, the well-conserved central region is the most important but may not be sufficient to express full activity. There are lines of evidence that the $\mathrm{N}$-terminal and $\mathrm{C}$ terminal regions of $14-\mathrm{kDa}$ lectins are buried in the molecules or involved in the inter-subunit association $(140,171)$.

A single conservative tryptophan (Trp68) had long
近、Drickamerのグループが明快な結論をだした(166、167)。 ラットのマンノース結合性レクチンのCRDとAsn結合型糖鎖の 複合体についてX-線解析がなされたことは先にも触れたが (143)、その結果、以下のことがわかった。第一に、糖結合に関 与するアミノ酸残基は、レクチンのC-末端付近の 25 残基からな る領域に位置する。第二に、二つの「酸一アミド対」、Glu185/ Asn187、およびGlu193/Asn205が協調的な水素結合を介してそ れぞれマンノースの3-位と4-位の水酸基を認識する。第三に、 これらの水素結合はカルシウムイオンによって厳密に規定され ている。Drickamerは、コンピュー夕画面上にマンノースをはに゙ め、いろいろな単糖分子のモデルを重ねあわせるという作業を おこない、Glu185/Asn187という「酸ーアミド対」が糖特異性を 決めるうえで重要と推定した。そこで、マンノース特異的レク チンを特徵づける「Glu-Pro-Asn」という配列モチーフをガラク トース特異的レクチンを特徵づける「Gln-Pro-Asp」というモ チーフに変えたところ(図1)、このマンノース結合性タンパクは ガラクトース特異的レクチンに衣替えしてしまったのである。 この変異体はマンノースに対する親和性を天然型の半分も失っ ていた(166)。

一方、S-型レクチンの構造と機能に関する研究は、C-型レ クチンほど進展していない。しかし、さまざまな種由来のS-型 レクチンの一次構造が数多くわかっているため、完全に保存さ れているアミノ酸はかなり限られる。これら保存残基の役割に ついては、部位特異的な变異法による解析(136) と削除变異体を もちいた解析(168)がある。われわれは保存性の親水性残基に着

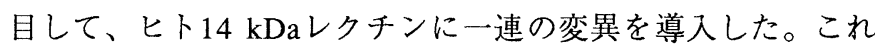
は、多くの糖結合タンパクの結合部位が、もっぱら親水性残基 で形成されているためだ(143、169)。疎水性パラメーターの解 析によると、S-型レクチンの中央部(14 kDaレクチンの30-90残基 目に相当)が親水性に富んでおり、また、ほとんどの保存残基が この領域に位置する。さらに、ゲノム解析によると、この中央 領域は一個のエクソンによってコードされている(98、99、 106、111、123)。これらの観察結果から、この領域がS-型レク チンの糖認識において中心的な役割を担っていると考えるのは 妥当であろう。実際、これら保存性の親水性残基であるHis44、 Asn46、Arg48、Asn61、Glu71、Arg73を置換すると、糖結合 活性はほとんど失われてしまう。これに対し、中央領域でも保 存性のあまり高くないLys63や、保存性は高くてもC-末端領域 にあるArg111やAsp125を置換しても、活性にはほとんど影響が ない(136、170)。しかし、削除変異体による解析によると、N末端やC-末端の10残基ほどを除くだけでレクチン活性は失われ てしまうという(168)。よって、保存された中央領域は、レクチ ンの機能上もっとも大切ではあるが、周辺部位もペプチド鎖の 正しい折りたたみのうえで重要なのだろう。中央部だけでは活 性を発揮するには不十分ということになる。14 kDaレクチンに ついては、これら周辺部位が分子中に埋もれているか、サブユ ニットの会合に関わっているという証拠もある(140、171)。 S-型レクチンでは、長らく一個の保存性トリプトファン 


$\begin{array}{ll}\text { [Man-type] } & \\ \text { MBP-A } & \text { Man } \\ \text { CON } & \text { GlcNAc, Man } \\ \text { ManR-4 } & \text { Man } \\ \text { GP120BP } & \text { Man } \\ \text { CHL } & \text { GlcNAc } \\ \text { L-SEL } & \text { Fuc+Sia } \\ \text { E-SEL } & \text { Fuc+Sia } \\ \text { P-SEL } & \text { Fuc+Sia } \\ & \\ \text { [Gal-type] } & \\ \text { ASGPR } & \text { Gal } \\ \text { KCR } & \text { Gal, Fuc } \\ \text { MACR } & \text { Gal } \\ \text { CPG } & \text { Gal, Fuc } \\ \text { FPG } & \text { Gal, Fuc } \\ \text { RSL } & \text { Gal } \\ \text { SPL } & \text { Gal } \\ \text { SUL } & \text { Gal } \\ \text { BAR } & \text { Gal } \\ \text { TUN } & \text { Gal } \\ & \\ \text { [Others] } & \\ \text { PSAP } & \text { Fuc, Man, Gal } \\ \text { LPSBP } & \text { LPS } \\ \text { FCER } & ? \\ \text { TM } & ? \\ \text { TETN } & ? \\ \text { IRP } & ? \\ \text { PSP } & ? \\ \text { AFP } & ? \\ & \end{array}$

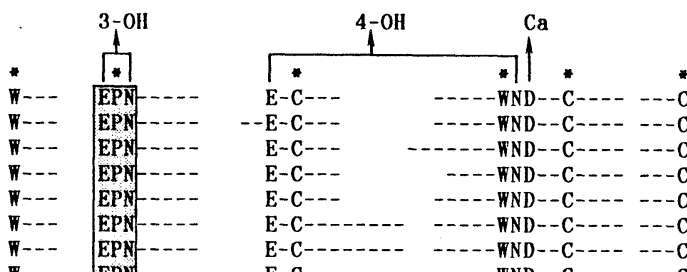

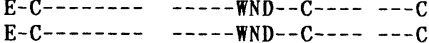

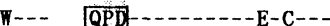

QPD - -

QPD -

QPD -

QPD -

$\mathrm{E}-\mathrm{C}-\mathrm{C-N}$

$\mathrm{E}-\mathrm{C}-\mathrm{C-N}$

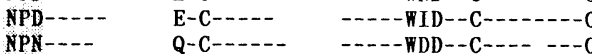

NPD----

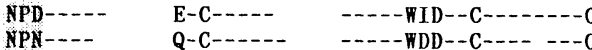

- - - WND--C--- - - -

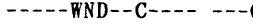

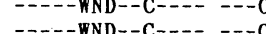

-.-- WND--C---- ---

$----W N D--C-\cdots---C$

$-\cdots-$ WND--C--- - - -

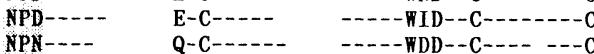

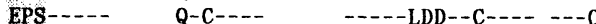

W-- EPA-

IPD

(2)

- - - LDD--C--- - -

EPT

E-C-D-

E-C-D-

E-C-D--

P-C-...-

E-C-D-

G-C-D

G-C-

QPD-- -

YPN-.-

W-- APS---

E-C-........... - WND--C-.- - J

Fig. 1. Sequence motifs defining sugar-binding specificities of C-type lectins. Only relevant residues are shown (others shown by dashed lines). Asterisks denote structurally invariant residues. Blanks represent deletions for maximum homology. Motifs, "EPN", specific for mannose-binding lectins and "QPD", specific for galactose-binding lectins are boxed, and corresponding regions in all sequences are shaded. Abbreviations; MBP-A, mannose-binding protein-A; CON, conglutinin; ManR-4, macrophage mannose receptor CRD-4; GP120BP, placental HIV gp120-binding protein; CHL, chicken hepatic lectin; L-, E-, P-SEL, L-, E-, P-selectins, respectively; ASGPR, hepatic asialoglycoprotein receptor; KCR, Kupffer cell receptor; MACR, macrophage receptor; CPG, cartilage proteoglycan core protein; FPG, fibroblast proteoglycan core protein; RSL, rattlesnake venom lectin; SUL, sea urchin lectin; BAR, barnacle lectin; TUN, tunicate lectin; PASP, major component of pulmonary surfactant apoprotein; LPSBP, cockroach lipopolysaccharide-binding protein; FCER, low affinity IgE receptor (CD23); TM, thrombomodulin; TETN, tetranectin; IRP, islet regenerating protein; PSP, pancreatic stone protein; AFP, smelt anti-freeze protein.

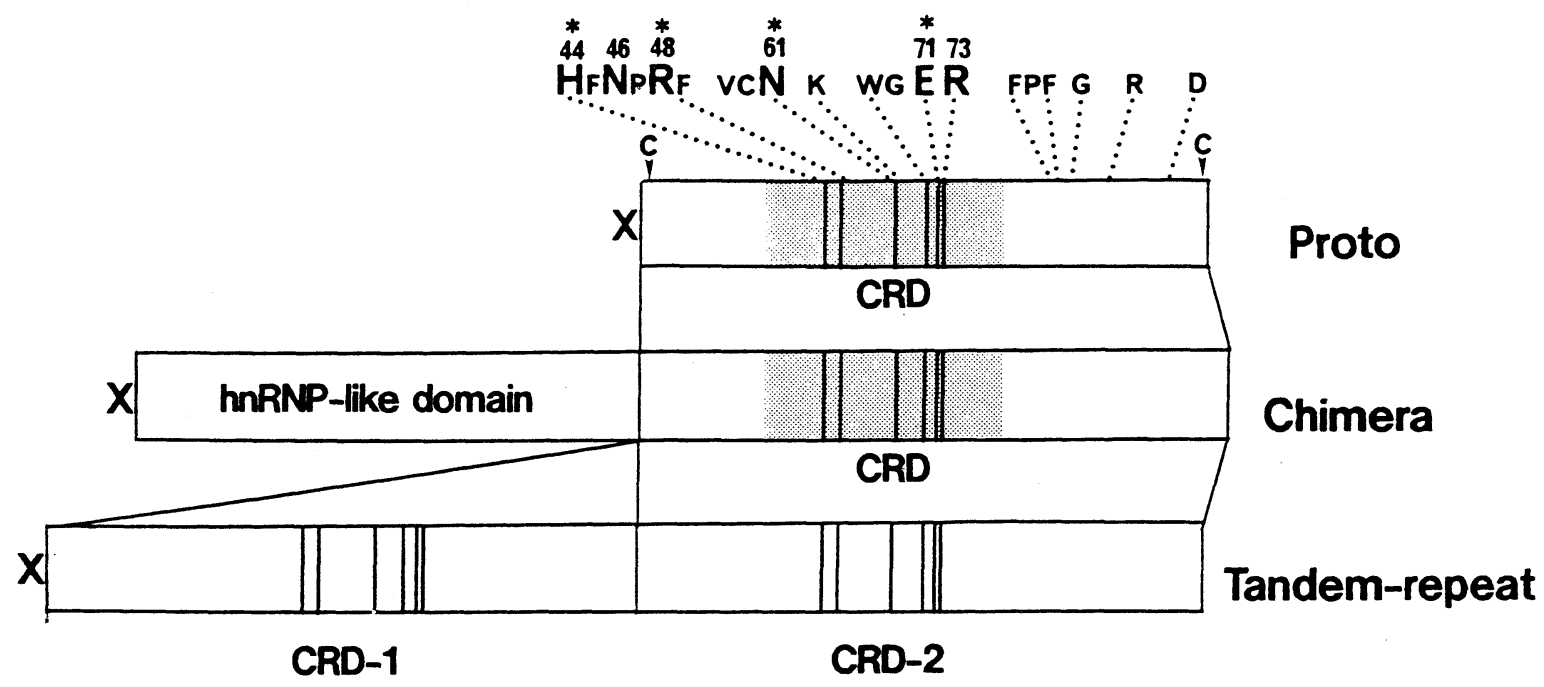

Fig. 2. Polypeptide architectures of $\beta$-galactoside-binding lectins. Representative conserved residues are shown above the prototype structure, among which perfectly conserved ones are denoted by asterisks (residue numbers are those of human 14-kDa lectin). Large capitals represent critical residues, possibly involved in the sugar-binding function shown by site-directed mutagenesis (136 and our unpublished result). Conservative central regions which proved to be encoded by a single exon are shaded. 
been believed to have an essential role in sugar binding $(115,172)$. However, Trp68 of the human 14-kDa lectin was shown to be less important, because it could be replaced with tyrosine with only a slight decrease in the sugar-binding ability (136). In fact, Rana egg 14-kDa lectin has tyrosine in the position corresponding to $\operatorname{Trp} 68$ (114).

To establish the structure-function relationship of Stype lectins, however, elucidation of the three-dimensional structure is of urgent necessity.

\section{E. General View}

\section{E-1. C-Type Lectins as "Bricolage Products"}

As described, each member of the C-type lectin family appears to have rather specialized functions. This is consistent with their distribution; though C-type lectins as a whole are widely found in the animal kingdom, individual molecules show rather restricted biological distribution. It will be hardly possible to find lectins having the same functions as hepatic lectin (asialoglycoprotein receptor) or lymphocytespecific antigens in invertebrates. There are also examples of very specialized C-type lectins such as antifreeze protein (only found in fishes living in polar seas; reviewed in 173) and snake venom hemagglutinin (exclusively found in the crotalid but scarcely in the elapid families; 69). Individual members of the C-type lectin family seem to have diverged, become tissuespecific (as seen from their designations, e.g., "macrophage receptor" and "T-lymphocyte specific antigen") as well as species-specific, and thus, obtained more specialized functions during the evolution of animals.

My own hypothesis concerning C-type lectins is as follows. It is well known that in primitive societies people often make up various tools from handy parts that originally had a completely different purposes. C. Levi-Straus, a cultural anthropologist, described this phenomenon as "bricolage" in contrast to products made by modern manufactures. F. Jacob pointed out that almost all biomolecules are the result of none other than bricolage (174). Then, we can consider that all animal species have utilized CRD as an extremely useful part to create a variety of carbohydrate-binding proteins with specialized functions during evolution under different circumstances; membrane-bound receptors or soluble proteins, having strict sugar selectivity like selectins or broad specificity like pulmonary surfactant proteins, and so on. C-Type lectins are no doubt "bricolage products".

A simple question then arises: Did the primitive (ancestral) CRD motif really have sugar-binding ability? In consideration of the facts that most of the reported CRD-containing proteins actually function as a lectin, the answer might be "yes". Since most of the invertebrate lectins so far characterized are galactose-specific and all of the soluble C-type lectins of vertebrates which have rather simple structures are
(Trp68)が糖結合のうえで中心的役割をはたしていると考えられ ていた(115、172)。しかし、ヒトの14 kDaレクチンでは、この トリプトファンはあまり重要ではないことが判明している。 Trp68をチロシンに置換しても、わずかな結合活性の減少をみる にとどまった(136)。実際の例として、カエル(Rana)卵由来14 kDaレクチンでは、Trp68に相当する位置がチロシンになってい た(114)。

言うまでもなく、S-型レクチンの三次構造が解明されなけ れば、このレクチンの構造一機能相関の問題も解決されない。

\section{E. 総合討論}

E-1.「ブリコラージュの産物」としてのC-型レクチン

以上みてきたように、C-型レクチン家系を構成するタンパ ク質は概して特殊化した機能をもつようだ。このことは、C-型 レクチンの分布と関係づけられそうである。すなわち、C-型レ クチンは、全体としては動物界にひろく存在しているが、各分 子についてみると比較的せまい生物分布を示す。たとえば、無 脊椎動物界で、肝レクチン(アシアロ糖タンパク受容体)や各種 リンパ球特異的抗原などとまったく同じ機能をしている分子を 見つけるのは無理だろう。特殊化したC-型レクチンの典型とし て、抗凍結タンパク質(極海域に棲息する魚類にのみ存在、文献 171)や、蛇毒の赤血球凝集素(もっぱらマムシ科に存在し、コブ ラ科にはない、文献69)が挙げられる。さらに、個々のC-型レク チンは種特異的であるばかりでなく、組織特異的でもあるよう だ。このことは、たとえば「マクロファージ受容体」、「リン パ球特異的抗原」といった名称からも察することができよう。

C-型レクチンに対する筆者の考えを以下に述べる。未開社 会では、本来の使途とは必ずしも関係のない手近な部品をもち いて、いろいろな道具を組み立てるという。文化人類学者、C. レヴィ=ストロースはこのことを近代工業と対比して、ブリコ ラージュ(鋳掛け屋仕事)と呼んだ。F.ヤコブによると、生物の 営みとはあまねくこの鋳掛け屋仕事にほかならない(174)。す心゙ ての動物は、それぞれの環境に応じて、CRDというこのうえも なく便利な部品を最大限に活用しながら、さまざまな機能分子 を創造してきたのではないだろうか。それらは受容体であった り、可溶性因子であったり、あるいはセレクチンのように厳密 な特異性をもつものから、肺サーファクタンタンパク質のよう に比較的広い特異性をもつものまで様々であったろう。C-型レ クチンは、まさに「ブリコラージュの産物」といえる。

ここで、素朴な疑問が生じる。原始CRDにはたして糖結合 能があったのだろうか。今までに報告された多くのCRD含有夕 ンパク質が、実際、レクチン機能をもっていることを考える と、この可能性は高いだろう。また、これまでに単離されてい るほとんどの無脊椎動物レクチンや、比較的簡単な構造をした 
also galactose-specific, the primitive CRD seems to have been galactose-specific.

As animal species diverged (speciated), individual molecular species may have well attained specialization. Some lectins may have maintained their sugar-binding ability during their metamorphosis to more sophisticated molecules such as receptors or collagenous proteins. On the other hand, some may have almost lost the sugar-binding ability while they acquired other functions. All these natural processes would have resulted in today's molecular diversity.

\section{E-2. Are S-Type Lectins "Bricolage Products"?}

Animal metal-independent $\beta$-galactoside-binding lectins have been regarded as "onco-developmental" proteins, based on their prominent occurrence in embryonic and tumorigenic tissues and cells $(4-7,175)$. No universal explanations for their raison d'etre have been given, though various hypotheses have been presented based on a variety of observations; i.e., cross-linking of glycoconjugates through carbohydrate recognition $(176,177)$, some function as an activated macrophage antigen $(117,126)$, prophylactic and therapeutic effect on some autoimmune diseases $(178,179)$, stimulant for macrophage to produce tumor-killing factor (180), involvement in metastasis of tumor cells (175), function as a negative cytostatic factor (105), function as a novel transformation growth factor (181), association with glucocorticoid-induced leukemia apoptosis (182), inhibition of fucosyltransferase action (183), etc. Though they are distributed ubiquitously, they still remain as "unsung heroes".

However, two recent findings revolutionalized our concept of S-type lectins; the occurence of invertebrate lectins, i.e., in nematode Caenorhabditis elegans $(92,129)$ and sponge Geodia cydonium (116b). Therefore, S-type lectins should have originated from a very early stage in the evolution of animals, probably in the Precambrian era (more than 600 million years ago). This suggests that they have much more fundamental role(s) than had ever been thought. At the same time, it follows that their partner molecules, possibly lactosaminoglycans, should have concurrently occurred in these primitive multicellular animals. To prove this, we have to accumulate more information on both lectins and glycoconjugates of invertebrate species.

In contrast to C-type lectins, S-type lectins do not seem to be bricolage products. For this discussion, however, we have to consider the possibility that we have only biased data because affinity adsorbents favorable for $\beta$-galactoside-binding lectins such as asialofetuin-agarose have been used for detection and isolation in most cases. Nevertheless, there are a number of proteins which were initially regarded as "nonlectin" proteins but later turned out to be identical to one of the known $\beta$-galactoside-binding lectins; e.g., IgE-binding protein (121), Mac-2 antigen (126), laminin-binding protein
脊椎動物のレクチンが、ガラクトース特異的であることを考え ると、原始CRDはガラクトース特異的だったのかもしれない。

様々な動物種が分化をとげ特殊化していくとき、各分子種 もまた特殊化していくのだろう。あるレクチンは糖結合能を保 ちつつ、受容体やコラーゲン様タンパク質といった洗練された 機能分子へと変容していったたろうし、あるものは進化の過程 で糖結合能を失ってしまい、代わりに新しい機能を獲得するこ ともあっただろう。このような自然のなす創造と模索の結果と して、今日われわれがみるような分子の多様性(ブリコラー ジュ)があるはずである。

\section{E-2. S-型レクチンは「ブリコラージュの産物」か ?}

金属非要求性の $\beta$-ガラクトシド結合性レクチンは、肧組 織や腫瘍組織における含量がとくに高いことから、「癌一発

生」関連タンパク質とみなされてきた(4-7、175)。しかし、こ のレクチンの役割については今だに定説がない。いろいろな観 察結果から推測されていることは、糖認識を介した複合糖鎖の 架橋(176、177)、活性化マクロファージ抗原としての機能 (117、126)、ある種の免疫疾患に対する予防、および治癒効果 (178、179)、マクロファージの腫瘍殺傷因子産生(180)、腫瘍細 胞転移反応への関与(175)、負の成長因子としての機能(105)、新 種の腫瘍成長因子としての機能(181)、グルココルチコイドで誘 導されるアポトーシスとの関連(182)、フコース転移酵素活性の 阻害(183)などである。S-型レクチンが偏在性の高いタンパク質 であることはまちがいないが、その役割は理解されずに、依然 として「unsung hero」の地位に甘んじている。

ところが最近、S-型レクチンに対する従来の概念を打ち破 るような二つの発見があった。原始的な無脊椎動物である線 虫、Caenorhabditis elegans(92、129) と海綿、Geodia cydonium (116b) から脊椎動物と相同なS-型レクチンが発見された。これ らの発見は、S-型レクチンが動物進化のかなり早い時期(おそら く先カンブリア期(今から約6億年以上前)に誕生したことを意味 する。これらの事実が示すことは、S-型レクチンの役割が依然 から考えられていたより、はるかに基本的だあるということで ある。同時に、本レクチンの伴侶となる分子(おそらくラクトサ ミノグリカン)も、やはりこれら原始的多細胞動物に存在し、機 能しているかもしれない。しかし、この仮説の証明には、無脊 椎動物のレクチンや複合糖鎖についての情報をもっと集めなけ ればならない。

C-型レクチンと比較すると、S-型レクチンにはあまりブリ コラージュの産物としての特色(多様性)が見られないが、この 判断には注意が必要である。というのは、われわれが今まで、 $\beta$-ガラクトシドに特異的なレクチンばかりを選びとってきた可 能性があるからだ。たとえば、レクチンの検出や単離には、 もっぱらアシアロフェツインーアガロースのような有用性の高 い吸着体が使われてきた。しかし、実際には、当初は非レクチ ンタンパクとして研究されていたものが、のちに既知の $\beta$-ガラ クトシド結合性レクチンであることが判明した例がたいへん多 い。IgE結合性タンパク質(121)、Mac-2抗原(126)、ラミニン結 
(127, 162), negative growth factor (105), transformation growth factor (181), and glucocorticoid-induced apoptosisasociated protein (182). All of them were found to be $\beta$-galactoside-specific. Therefore, all S-type lectins so far studied are $\beta$-galactoside-binding lectins, and there is no diversity in sugar-binding specificity.

On the other hand, from the viewpoint of molecular diversity, S-type lectins seem to be also bricolage products. In man, for example, four members of this protein family are already known; i.e., two proto types (a well-characterized placenta-type lectin and a hepatoma-type lectin predicted by cDNA cloning), one chimera type, and eosinophil CharcotLeyden crystal (CLC) protein (lysophospholipase) [CLC protein is a novel member of the $\mathrm{S}$-type lectin family reported very recently, though its sugar-binding activity has not been confirmed (184)]. The number should be larger because the occurrence of a tandem-repeat type in man (a homologue to the rat $36-\mathrm{kDa}$ lectin; 130 ) is very likely. Therefore, at least five $\beta$-galactoside-binding lectins are present in man.

To summarize, S-type lectins appear to have conserved the structural feature of cytoplasmic proteins and the functional one of $\beta$-galactoside binding. From these viewpoints, S-type lectins are "antithesis" to C-type lectins.

\section{F. Concluding Remarks}

Jacob's remark that all proteins are "bricolage products" is readily acceptable in the case of C-type lectins, while it seems harder to apply to S-type lectins, which are less diverse especially as regards carbohydrate specificity. I wish to enphasize that such a conservative feature in spite of molecular diversity should represent the biological importance of the recognition of $\beta$-galactoside-containing structures through the whole history of multicellular animals.

C-Type and S-type lectins are really distinct carbohydrate-binding proteins, so to speak, in both their origins and nature. This makes a clear contrast (or symmetry) between the two families. In particular, difference in their cytochemical localization reminds us of "habitat segregation". K. Imanishi, a field biologist, stated that evolution is an increase in the density of the habitat segregation of the specia (185). This concept proposed originally for ecosystems seems to be applicable in some degree to "molecular species societies".

In spite of extensive studies on animal lectins, we are still far from a complete understanding of their essentials. For example, antifreeze activity which had never been anticipated was recently demonstrated for the $\mathrm{C}$-type rattlesnake venom lectin (186), hepatic lectin was recently found to be also present in intestine (187), and CLC protein which has lysophospholipase activity associated with eosinophil inflamation proved to be a new member of the S-type lectin family (184). Such surprises, however, may be attributed to
合性タンパク質(127、162)、負の成長因子(105)、腫瘍成長因子 (181)、グルココルチコイド誘導性アポトーシス関連タンパク (182)などがこれに相当する。また、今まで見つかったたS-型レ クチンの仲間は例外なく $\beta$-ガラクトシド特異的であって、他の 特異性をもつものは見つかっていない。

一方、分子の多様性に着目すると、S-型レクチンもブリコ ラージュの産物としての様相を呈してくる。たとえば、ヒトで はすでに四種のS-型レクチンが知られている。すなわち、二種 のプロト型レクチン(よく調べられている胎盤型のレクチンと cDNAクローニングからその存在が示されている肝癌型のレク チン)、一種のキメラ型レクチン、そして好酸球のCharcot-Leyden結晶(CLC)タンパク(リゾホスフォリパーゼ)である[CLCタン パクはごく最近報告されたS-型レクチン家系の新しい構成員。 糖結合活性についてはまだ確認されていない(184)]。しかも、 これは過小評価した数であって、ラットの $36 \mathrm{kDa}$ レクチンに相 当する直列反復型のレクチン(130)がヒトにも存在する可能性は 高い。したがって、五種類以上の $\beta$-ガラクトシド結合性レクチ ンの仲間がヒトに存在することになる。

要約すると、S-型レクチンは細胞質タンパクとしての構造 上の特徴と、 $\beta$-ガラクトシド結合性という機能上の特徵を合わ せもち、これらをつよく保っている。比較分析的な立場から考 察すれば、S-型レクチンはC-型レクチンの「アンチテーゼ」と して成り立とう。

\section{F.おわりに}

「すべてのタンパク分子はブリコラージュの産物である」 というF.ヤコブが示した見解は、C-型レクチンでは即座に受け 入れられるが、S-型レクチンにはそのまま適用しにくい。S-型 レクチンは、分子レベルでは一応の多様性を示すものの、糖特 異性に関しては多様性を欠いているからだ。このようにS-型レ クチンの糖特異性が保たれているのは、 $\beta$-ガラクトシド糖鎖を 認識するという現象が、多細胞動物の生物史上、きわめて重要 であったことを物語る。筆者の主張はまさにここにある。

C-型レクチンとS-型レクチンはいわば、生まれも育ちも まったく異なるタンパク質である。両者の性質はことごとく対 照的であり("対称的"とさえ言える)、なかでも、両レクチンの局 在性の違いは、われわれに「棲みわけ」さえ思い起させる。野 外生物学者であった今西錦司は、「進化とは(生物)種における 棲みわけの密度化にほかならない」という金言を残しているが (185)、生態学で生まれた棲みわけの概念が、「分子種社会」に どのように適用できるのか、今後、考察してみる価值がありそ うだ。

さて、動物レクチンに対するこれまでの広範な研究にもか かわらず、このタンパク質に対するわれわれの知識は、いまだ その本質的理解には達していないようである。というのは、わ れわれを驚かす予期せぬ知見がつぎつぎと得られているから だ。たとえば、ガラガラ蛇毒のC-型レクチンに、最近、抗凍結 活性が見いだされた(186)。また、いわゆる"肝"レクチンは"腸" でも見つかっている(187)。好酸球の炎症関連リゾフォスフォリ パーゼ (CLCタンパク) がS-型レクチンの仲間であったのは驚 きである(184)。しかし、このような意外な事実の成因も、単に 
our prejudice or ignorance, that is, we cannot see the wood for the trees.

When the answer to the significance of cytoplasmic properties of S-type lectins is given, we will understand a new principle of the life. Why are $S$-type lectins always specific for $\beta$-galactosides? Or alternatively, why were $\beta$-galactosides chosen as thier ligands? Unfortunately, our current knowledge is too limited to answer these basic questions. It seems to be the time to reconsider the present state in which too much emphasis is put on higher animals, and instead, to pay more attention to simpler and more primitive animals such as nematode, an excellent model animal (188). Lastly, I wish to emphasize the finding of the nematode lectin as "the dawn of glycobiology in nematode".

\section{Acknowledgement}

I wish to thank Prof. Ken-ichi Kasai for his critical reading of the manuscript. This work was supported in part by grant-in-aid for scientific research from the Ministry of Education, Science and Culture of Japan, and by The Naito Foundation.
われわれの偏見や無知を表しているのに過ぎないのかもしれな い。木を見て森を見ずということか。

「なぜS-型レクチンが細胞質タンパクなのか」に対する答 えが用意できたとき、われわれは生命についての新しい原理を 見いだすことになるかもしれない。繰り返しになるが、なぜS型レクチンはついつも $\beta$-ガラクトシドに特異的なのだろう。あ るいは、なぜ他の糖鎖でなく $\beta$-ガラクトシドが選ばれたの か……残念ながら、この基本的な問いにさえ、われ われは満足な答えがだせない。その一因として、高等動物に偏 りがちな現在の糖鎖生物学、さらには生命科学の潮流が挙げら れないだろうか。いまこそ、線虫のような優れたモデル動物 (188)に目をむけるべきときであろう。最後に、この原始的な小 動物に相同なレクチンが発見されたことを、「線虫における糖 鎖生物学の夜明け」として銘記したい。

\section{References}

1. Sharon, N., and Lis, H. (1989) Lectins, Chapman and Hall Ltd., London

2. Drickamer, K. (1988) J. Biol. Chem. 263, 9557-9560

3. Drickamer, K. (1989) Ciba Found. Symp. 145, 45-58

4. Barondes, S.H. (1984) Science 223, 1259-1264

5. Kasai, K. (1990) in Advances in Lectin Research (Franz, H., ed.) Vol. 3, pp. 10-35, VEB Verlag Volk und Gesundheit, Berlin

6. Caron, M., Bladier, D., and Joubert, R. (1990) Int. J. Biochem. 22, 1379-1385

7. Harrison, L. (1991) in Lectin Reviews Vol. 1, pp. 17-39, Sigma, St. Louis, MO.

8. Rosen, S.D., Imai, Y., Singer, M.S., and Huang, K. (1992) Trends Glycosci. Glycotechnol. 4, 1-13

9. Goelz, S.E. (1992) Trends Glycosci. Glycotechnol. 4, 14-24

10. Larsen, E. (1992) Trends Glycosci. Glycotechnol. 4, 25-31

11. High, S., and Dobberstein, B. (1992) Curr. Opin. Cell Biol. 4, 581-586

12. Pontow, S.E., Kery, V., and Stahl, P.D.(1992) in International Review of Cytology: A Survey of Cell Biology (Friedlander M., and Mueckler, M. eds.) Vol. 137B (Molecular Biology of Receptors and Transreporters), pp. 221-244, Academic Press, San Diego

13. Lasky, L.A., Singer, M.S., Yednock, T.A., Dowbenko, D., Fennie, C., Rodriguez, H., Nguyen, T., Stachel, S., and Rosen, S.D. (1989) Cell 56, $1045-1055$

14. Siegelman, M.H., Van De Rijn, M., and Weissman, I.L. (1989) Science 243, 1165-1172

15. Ord, D.C., Ernst, T.J., Zhou, L.-J. Rambaldi, A., Spertini, O., Griffin, J., and Tedder, T.F. (1990) J. Biol. Chem. 265, 7760-7767

16. Bevilacqua, M.P., Stengelin, S., Gimbrowne, M.A., Jr., and Seed, B. (1989) Science 243, 1160-1164

17. Collins, T., Williams, A., Johnston, G.I., Kim, J., Eddy, R., Shows, T., Gimbrone, M.A., Jr., and Bevilacqua, M.P. (1991) J. Biol. Chem. 266, 2466-2473

18. Johnston, G.I., Cook, R.G., and McEver, R.P. (1989) Cell 56, 1033-1044

19. Johnston, G.I., Bliss, G.A., Newman, P.J., and McEver, R.P. (1990) J. Biol. Chem. 265, 21381-21385

20. Lennartz, M.R., Cole, F.S., Shepherd, V.L., Wileman, T.E., and Stahl, P.D.(1987) J. Biol. Chem. 262, 9942-9944

21. Taylor, M.E., Conary, J.T., Lennartz, M.R., Stahl, P.D., and Drickamer, K. (1990) J. Biol. Chem. 265, 12156-12162

22. Ezekowitz, R.A., Sastry, K., Bailly, P., and Warner, A.(1990) J. Exp. Med. 172, 1785-1794

23. Taylor, M.E., Bezouska, K., and Drickamer, K. (1992) J. Biol. Chem. 267, 1719-1726

24. Jackman, R.W., Beeler, D.L., Fritze, L., Soff, G., and Rosenberg, R.D. (1987) Proc. Natl. Acad. Sci. USA 84, 6425-6429

25. Suzuki, K., Kusumoto, H., Deyashiki, Y., Nishioka, J., Maruyama, I., Zushi, M., Kawahara, S., Honda, G., Yamamoto, S., and Horiguchi, S. (1987) EMBO J. 6, 1891-1897

26. Wen, D., Dittman, W.A., Ye, R.D., Deaven, L.L., Majerus, P.W., and Sadler, J.E. (1987) Biochemistry 26, 4350-4357

27. Kurosawa, S., Stearn, O., Jackson, K.W., and Esmon, C.T. (1988) J. Biol. Chem. 263, 5993-5996

28. Suzuki, K., Hayashi, T., Nishioka, J., Kosaka, Y., Zushi, M., Honda, G., and Yamamoto, S. (1989) J. Biol. Chem. 264, 4872-4876

29. Hayashi, T., Zushi, M.,-Yamamoto, S., and Suzuki, K. (1990) J. Biol. Chem. 265, 20156-20159

30. Drickamer, K., Mamon, J.F., Binns, G., and Leung, J.O. (1984) J. Biol. Chem. 259, 770-778

31. Spiess, M., Schwartz, A.L., and Lodish, H.F. (1985) J. Biol. Chem. 260, 1979-1982

32. Leung, J.O., Holland, E.C., and Drickamer, K. (1985) J. Biol. Chem. 260, 12523-12527 
33. Geffen, I., and Spiess, M. (1992) in International Review of Cytology: A Survey of Cell Biology (Friedlander M., and Mueckler, M. eds.) Vol. 137B (Molecular Biology of Receptors and Transreporters), pp. 181-219, Academic Press, San Diego

34. Drickamer, K. (1981) J. Biol. Chem. 256, 5827-5839

35. Bezouska, K., Crichlow, G.V., Rose, J.M., Taylor, M.E., and Drickamer, K. (1991) J. Biol. Chem. 266, 11604-11609

36. Hoyle, G.W., and Hill, R.L.(1988) J. Biol. Chem. 263, 7487-7492

37. Hoyle, G.W., and Hill, R.L. (1991) J. Biol. Chem. 266, 1850-1857

38. Ii, M., Kurata, H., Itoh, N., Yamashina, I., and Kawasaki. T. (1990) J. Biol. Chem. 265, 11295-11298

39. Sato, M., Kawakami, K., Osawa, T., and Toyoshima, S. (1992) J. Biochem. (Tokyo) 111, 331-336

40. Kikutani, H., Inui, S., Sato, R., Barsumian, E.L., Owaki, H., Yamasaki, K., Kaisho, T., Uchibayashi, N., Hardy, R.R., Hirano, T., Tsunasawa, S., Sakiyama, F., Suemura, M., and Kishimoto, T. (1986) Cell 47, 657-665

41. Ikuta, K., Takami, M., Kim, C.W., Honjo, T., Miyoshi, T.,Tagaya, Y., Kawabe, T., and Yodoi, J. (1987) Proc. Natl. Acad. Sci. USA 84, 819-823

42. Suter, U., Bastos, R., and Hofstetter, H. (1987) Nucleic Acids Res. 15, 7295-7308

43. Bettler, B., Hofstetter, H., Rao, M., Yokoyama, W.M., Kilchherr, F., and Conrad, D.H. (1989) Proc. Natl. Acad. Sci. USA 86, 7566-7570

44. Vercelli, D., Helm, B., Marsh, P., Padlan, E., Geha, R.S., and Gould, H. (1989) Nature 338, 649-651

45. Yokoyama, W.M., Jacob, L.B., Kanagawa, O., Shevach, E.M., and Cohen, D.I. (1989) J. Immunol. 143, 1379-1386

46. Nakayama, E., Von Hogen, I., and Parnes, J.R. (1989) Proc. Natl. Acad. Sci. USA 86, 1352-135647. Houchins, J.P., Yabe, T., McSherry, C., and Bach, F.H. (1991) J. Exp. Med. 173, 1017-1020

48. Yokoyama, W.M., Ryan, J.C., Hunter, J.J., Smith, H.R.C., Stark, M., and Seaman, W.E. (1991) J. Immunol. 147, $3229-3236$

49. Cutris, B.M., Scharnowske, S., and Watson, A.J. (1992) Proc. Natl. Acad. Sci. USA 89, 8356-8360

50. Drickamer, K., Dordal, M.S., and Reynolds, L. (1986) J. Biol. Chem. 261, 6878-6887

51. Drickamer, K., and McCreary, V. (1987) J. Biol. Chem. 262, 2582-2589

52. Lee, Y.-M., Leiby, K.R., Allar, J., Paris, K., Lerch, B., and Okarma, T.B. (1991) J. Biol. Chem. 266, 2715-2723

53. Linacott, W.D., Ranken, R., and Triglia, R.P. (1978) J. Immunol. 121, 658-664

54. Ikeda, K., Sannoh, T., Kawasaki, N., Kawasaki, T., and Yamashina, I. (1987) J. Biol. Chem. 262, 7451-7454

55. Schweinle, J.E., Nishiyasu, M., Ding, T.Q., Sastry, K., Gillies, S.D., and Ezekowitz, A.B. (1993) J. Biol. Chem. 268, 364-370

56. Benson, B., Hawgood, S., Schilling, J., Clements, J., Damm, D., Cordell, B., and White, R.T. (1985) Proc. Natl. Acad. Sci. USA 82, 63796383

57. White, R.T., Damm, D., Miller, J., Spratt, K., Schilling, J., Hawgood, S., Benson, B., and Cordel, B. (1985) Nature 317, 361-363

58. Floros, J., Steinbrink, R., Jacobs, K., Phelps, D., Kriz, R., Recny, M., Sultzman, L., Jones, S., Taeusch, H.W., Frank, H.A., and Fritsh, E.F. (1986) J. Biol. Chem. 261, 9029-9033

59. Haagsman, H.P., Haywood, S., Sargeant, T., Buckley, D., White, R.T., Drickamer, K., and Benson, B.J. (1987) J. Biol. Chem. 262, 1387713880

60. Childs, R.A., Wright, J.R., Ross, G.F., Yuen, C.-T., Lawson, A.M., Chai, W., Drickamer, K., and Feizi, T. (1992) J. Biol. Chem. 267, 99729979

61. Shimizu, H., Fisher, J.H., Papst, P., Benson, B., Lau, K., Mason, R.J., and Voelker, D.R. (1992) J. Biol. Chem. 267, 1853-1857

62. Lu, J., Willis, A.C., and Reid, K.B.M. (1992) Biochem. J. 284, 795-802

63. Crouch, E., Rust, K., Veile, R., Donis-Keller, H., and Grosso, L. (1993) J. Biol. Chem. 268, 2976-2983

64. Doege, K., Fernandez, P., Hassell, J.R., Sasaki, M., and Yamada, Y. (1986) J. Biol. Chem. 261, 8108-8111

65. Sai, S., Tanaka, T., Kosher, R.A., and Tanzer, M.L. (1986) Proc. Natl. Acad. Sci. USA 83, 5081-5085

66. Krusius, T., Gehlsen, K.R., and Rouslahti, E. (1987) J. Biol. Chem. 262, 13102-13125

67. Halberg, D.F., Proulx, G., Doege, K., Yamada, Y., and Drickamer, K. (1988) J. Biol. Chem. 263, 9486-9490

68. Ohsaka, A. (1979) in Snake Venoms (Lee, C.-Y. ed.) pp. 480-546, Springer-Verlag, Berlin

69. Ogilvie, M.L., and Gartner, T.K. (1984) J. Herpetol. 18, 285-290

70. Gartner, T.K., and Ogilvie, M.L. (1984) Biochem. J. 224, 301-307

71. Hirabayashi, J., Kusunoki, T., and Kasai, K. (1991) J. Biol. Chem. 266, 2320-2326

72. Usami, Y., Fujimura, Y., Suzuki, M., Ozeki, Y., Nishio, K., Fukuki, H., and Titani, K. (1993) Proc. Natl. Acad. Sci. USA 90, 928-932

73. Ogilvie, M., Wilson, J., and Gartner, T.K. (1989) Thromb. Haemost. 62, 704-707

74. Atoda, H., Hyuga, M., and Morita, T. (1991) J. Biol. Chem. 266, 14903-14911

75. Takeya, H., Nishida, S., Miyata, T., Kawada, S., Saisaka, Y.,Morita, T., and Iwanaga, S. (1992) J. Biol. Chem. 267, 14109-14117

76. Inoue, S., Kogaki, H., Ikeda, K., Samejima, Y., and Omori-Satoh, T. (1991) J. Biol. Chem. 266, 1001-1007

77. Suzuki, T., Takagi, T., Furukohri, T., Kawamura, K., and Nakauchi, M. (1990) J. Biol. Chem. 265, 1274-1281

78. Giga, Y., Ikai, A., and Takahashi, K. (1987) J. Biol. Chem. 262, 6197-6203

79. Takahashi, H., Komano, H., Kawaguchi, N., Kitamura, N., Nakanishi, S., and Natori, S. (1985) J. Biol. Chem. 260, 12228-12233

80. Kubo, T., and Natori, S. (1987) Eur. J. Biochem. 168, 75-82

81. Jomori, T., and Natori, S. (1991) J. Biol. Chem. 266, 13318-13323

82. Muramoto, K., and Kamiya, H. (1986) Biochim. Biophys. Acta 874, 285-295

83. Muramoto, K., and Kamiya, H. (1990) Biochim. Biophys. Acta 1039, $42-51$

84. Kawaguchi, N., Komano, H., and Natori, S. (1991) Dev. Biol. 144, 86-93

85. De Caro, A.M., Bonicel, J.J., Rouimi, P., De Caro, J.C., Sarles, H., and Rovery, M. (1987) Eur. J. Biochem. 168, 201-207

86. Rouquier, S., Verdier, J.-M., Iovanna, J., Dagorn, J.-C., and Giorgi, D. (1991) J. Biol. Chem. 266, 786-791

87. Terazono, K., Yamamoto, H., Takasawa, S., Shiga, K., Yonemura, Y., Tochino, Y., and Okamoto, H. (1988) J. Biol. Chem. 263, 2111-2114

88. Watanabe, T., Yonekura, H., Terazono, K., Yamamoto, H., and Okamoto, H. (1990) J. Biol. Chem. 265, $7432-7439$

89. Fuhlendorff, J., Clemmensen, I., and Magnusson, S. (1987) Biochemistry 26, 6757-6764

90. Ewart, K.V., Rubinsky, B., and Fletcher, G.L. (1992) Biochem. Biophys. Res. Commun. 185, 335-340

91. Ng, N.F., Trinh, K.Y., and Hew, C.L. (1986) J. Biol. Chem. 261. 15690-15695 
Trends in Glycoscience and Glycotechnology Vol. 5 No. 24 (July 1993) pp. 251-270

92. Hirabayashi, J., Satoh, M., and Kasai, K. (1992) J. Biol. Chem. 267, 15485-15490

93. Gitt, M.A. and Barondes, S.H. (1986) Proc. Natl. Acad. Sci. USA 83, 7603-7607

94. Hirabayashi, J., and Kasai, K. (1988) J. Biochem. (Tokyo) 104, 1-4

95. Couroud, P.-O., Casentini-Borocz, D., Bringman, T.S., Griffith, J., McGrogan, M., and Nedwin, G.E. (1989) J. Biol. Chem. 264, 1310-1316

96. Abbott, W.M., and Feizi, T. (1989) Biochem. J. 259, 291-294

97. Hirabayashi, J., Ayaki, H., Soma, G., and Kasai, K. (1989) Biochim. Biophys. Acta 1008, 85-91

98. Gitt, M.A., and Barondes, S.H. (1991) Biochemistry 30, 82-89

99. Gitt, M.A., Massa, S.M., Leffler, H., and Barondes, S.H. (1992) J. Biol. Chem. 267, 10601-10606

100. Ohsawa, F., Hirano, F., and Natori, S. (1990) J. Biochem. (Tokyo) 107, 431-434

101. Clerch, L.B., Whitney, P., Hass, M., Brew, K., Miller, T., Werner, R., and Massaro, D. (1988) Biochemistry 27, $692-699$

102. Raz, A., Carmi, P., and Pazerini, G. (1988) Cancer Res. 48, 645-649

103. Wilson, T.J.G., Firth, M.N., Powell, J.T., and Harrison, F.L. (1989) Biochem. J. 261, 847-852

104. Cooper, D.N.W., and Baronds, S.H. (1990) J. Cell Biol. 110,1681-1691

105. Wells, V., and Mallucci, L. (1991) Cell 64, 91-97

106. Chiariotti, L., Wells, V., Bruni, C.B., and Mallucci, L. (1991) Biochim. Biophys. Acta 1089, 54-60

107. Abbótt, W.M., Mellor, A., Edwards, Y., and Feizi, T. (1989) Biochem. J. 259, 283-290

108. Merkle, R.K., Zhou, Q., Schultz, T.D., Harper, W.B., and Cummings, R.D. (1989) Arch. Biochem. Biophys. 274, 404-416

109. Ohyama Y., Hirabayashi J., Oda, Y., Oono, S., Kawasaki, H., Suzuki, K., and Kasai , K. (1986) Biochem. Biophys. Res. Commun. 134, 5156

110. Hirabayashi, J., Kawasaki, H., Suzuki, K., and Kasai, K. (1987) J. Biochem. (Tokyo) 101, 775-787

111. Ohyama, Y., and Kasai, K. (1988) J. Biochem. (Tokyo) 104, 173-177

112. Sakakura, Y., Hirabayashi, J., Oda, Y., Ohyama, Y., and Kasai, K. (1990) J. Biol. Chem. 265, 21573-21579

113. Marschal, P., Herrmann, J., Leffler, H., Barondes, S.H., and Cooper, D.N.W. (1992) J. Biol. Chem. 267, 12942-12949

114. Ozeki, Y., Matsui, T., Nitta, K., Kawauchi, H., Takayanagi, Y., and Titani, K. (1991) Biochem. Biophys. Res. Commun. 178, 407-413

115. Paroutaud, P., Levi, G., Teichberg, V.I., and Strosberg, A.D. (1987) Proc. Natl. Acad. Sci. USA 84, 6345-6348

116a.Muramoto, K., and Kamiya, H. (1992) Biochim. Biophys. Acta 1116, 129-136

116b.Pfeifer, K., Haasemann, M., Gamulin, V., Bretting., H., Fahrenholz, F., and Muller, W.E.G. (1993) Glycobiology 3, 179-184

117. Cherayil, B.J., Chaitovitz, S., Wong, C., and Pillai, S. (1990) Proc. Natl. Acad. Sci. USA 87, 7324-7328

118. Robertson, M.W., Albrandt, K., and Liu, F.-T. (1990) Biochemistry 29, 8093-8100

119. Raz, A., Carmi, P., Raz, T., Hogan, V., Mohamed, A., and Wolman, S.R. (1991) Cancer Res. 51, 2173-2178

120. Oda, Y., Leffler, H., Sakakura, Y., Kasai, K., and Barondes, S.H. (1991) Gene (Amsterdam) 99, 279-283

121. Albrandt, K., Orida, N.K., and Liu, F.-T. (1987) Proc. Natl. Acad. Sci. USA 84, 6859-6863

122. Leffler, H., Masiarz, F.R., and Barondes, S.H. (1989) Biochemistry 28, 9222-9229

123. Gritzmacher, C.A., Mehl, V.S., and Liu, F.-T. (1992) Biochemistry 31, 9533-9538

124. Jia, S., and Wang, J.L. (1988) J. Biol. Chem. 263, 6009-6011

125. Raz, A., Pazerini, G., and Carmi, P.(1989) Cancer Res. 49, 3489-3493

126. Cherayil, B.J., Weiner, S.J., and Pillai, S. (1989) J. Exp. Med. 170, 1959-1972

127. Woo, H.-J., Shaw, L.M., Messier, J.M., and Mercurio, A.M. (1990) J. Biol. Chem. 265, 7097-7099

128. Anderson, R.L., and Wang, J.L. (1992) Trends Glycosci. Glycotechnol. 4, 43-52

129. Hirabayashi, J., Satoh, M., Ohyama, Y., and Kasai, K. (1992) J. Biochem. (Tokyo) 111, 553-555

130. Oda, Y., Herrmann, J., Gitt, M., Turck, C.W., Burlingame, A.L., Barondes S.H., and Leffler, H. (1993) J. Biol. Chem. 268, 5929-5939

131. Beyer, E.C., and Barondes, S.H. (1982) J. Cell Biol. 92, 23-27

132. Hirabayashi J., and Kasai, K. (1984) Biochem. Biophys. Res.Commun. 122, 938-944,

133. Akimoto, Y., Obinata, A., Hirabayashi, J., Sakakura, Y., Endo, H., Kasai, K., and Hirano, H. (1993) Exp. Cell Res. 205, 251-260

134. Poore, S., Fortel, R.A., and Lamar, E. (1981) J. Mol. Biol. 153, 273-289

135. Whitney, P.L., Powell, J.T., and Sanford, G.L.(1986) Biochem. J. 238, 683-689

136. Hirabayashi, J., and Kasai, K. (1991) J. Biol. Chem. 266, 23648-23653

137. Tracey, B.M., Feizi, T., Abbott, W.M., Carruthers, R.A., Green, B.N., and Lawson, A.M. (1992) J. Biol. Chem. 267, 10342-10347

138. Frigeri, L.G., Robertson, M.W., and Liu, F.-T. (1990) J. Biol. Chem. 265, 20763-20769

139. Cooper, D.N.W., and Barondes, S.H. (1990) J. Cell Biol. 110, 1681-1691

140. Harrison, F.L., and Wilson, T.J.G. (1992) J. Cell Sci. 101, 635-646

141. Butterfield, H.H., Ackerman, S.J., Scott, R.E., Poerre, R.V., and Greich, G.J. (1984) Exp. Hematol. 12, 163-169

142. Weis, W.I., Kahn, R., Fourme, R., Drickmer, K., and Hendrickson, W.A. (1991) Science 254, 1608-1615

143. Weis, W.I., Drickamer, K., and Hendrickson, W.A. (1992) Nature 360, 127-135

144. Lodish, H.F., Kong, N., and Wikstrom, L. (1992) J. Biol. Chem. 267, 12753-12760

145. Lee, R.T., Rice, K.G., Rao, B.N.N., Ichikawa, Y., Barthel, T., Piskarev, V., and Lee, Y.C. (1989) Biochemistry 28, $8351-8358$

146. Lee, R.T., Lin, P., and Lee, Y.C. (1984) Biochemistry 23, 4255-4261

147. Lee, R.T., Ichikawa, Y., Fay, M., Drickamer, K., Shao, M.-C., and Lee, Y.C. (1991) J. Biol. Chem. 266, 4810-4815

148. Berg, E.L., Robinson, M.K., Mansson, O., Butcher, E.C., and Magnani, J.L. (1991) J. Biol. Chem. 266, $14869-14872$

149. Polley, M., Phillip, M.L., Wayner, E., Nudelman, E., Singhal, A.K., Hakomori, S., and Paulson, J. (1991) Proc. Natl. Acad. Sci. USA 88, 6224-6228

150. Foxall, C., Watson, S.R., Dowbenko, D., Fennie, C., Lasky, L.A., Kiso, M., Hasegawa, A., Asa, D., and Brandley, B.K. (1992) J. Cell Biol. 117, 895-902

151. Erbe, D.V., Wolitzky, B.A., Presta, L.G., Norton, C.R., Ramos, R.T., Burns, D.K., Rumberger, J.M., Rao, B.N.N., Foxall, C., Brandley, B.K., and Lasky, L.A. (1992) J. Cell Biol. 119, 215-227

152. Imai, Y., Lasky, L.A., and Rosen, S.D.(1993) Nature 361, 555-557 
153. Leffler, H., and Barondes, S.H. (1986) J. Biol. Chem. 261, 10119-10126

154. Sparrow, C.P., Leffler, H., and Barondes, S.H. (1987) J. Biol. Chem. 262, 7383-7390

155. Abbott, M.W., Hounsell, E.F., and Feizi, T. (1988) Biochem. J. 252, 283-287

156. Lee, R.T., Ichikawa, Y., Allen, H.J., and Lee, C.Y. (1990) J. Biol. Chem. 265, 7864-7871

157. Ahmed, H., Allen, H.J., Sharma, A., and Matta, K.L. (1990) Biochemistry 29, 5315-5319

158. Sato, S., and Hughes, R.C. (1992) J. Biol. Chem. 267, 6983-6990

159. Wen, D.X., Livingston, B.D., Medzihradszky, K.F., Kelm, S., Burlingame, A.L., and Paulson, J.C. (1992) J. Biol. Chem. 267, 21011-21019

160. Merkle, R.K., and Cummings, R.D. (1988) J. Biol. Chem. 263, 16143-16149

161. Cooper, D.N.W., Massa, S.M., and Barondes, S.H. (1991) J. Cell Biol. 115, 1437-1448

162. Castronovo, V., Luyten, F., van den Brule, F., and Sobel, M.E. (1992) Arch. Biochem. Biophys. 297, 132-138

163. Solomon, J.C., Stoll, M.S., Penfold, P., Abbott, W.M., Childs, R.A., Hanfland, P., and Feizi, T.(1991) Carbohydr. Res. 213, 293-307

164. Zhou, Q., and Cummings, R.D. (1993) Arch. Biochem. Biophys. 300, 6-17

165. Oda, Y., and Kasai, K.(1984) Biochem. Biophys. Res. Commun. 123, 1215-1220

166. Drickamer, K. (1992) Nature 360,183-186

167. Hirabayashi, J. (1993) Trends Glycosci. Glycotechnol. 5, 33-36

168. Abbott, M.W., and Feizi, T.(1991) J. Biol. Chem. 266, 5552-5557

169. Quiocho, F.A.(1986) Annu. Rev. Biochem. 55, 287-315

170. Hirabayashi, J., and Kasai, K. (1993) Glycobiology (in press)

171. Hirabayashi, J., and Kasai, K. (1992) J. Chromatogr. 597, 181-187

172. Levi, G., and Teichberg, V.I.(1981) J. Biol. Chem. 256, 5735-5740

173. Davies, P.L., and Hew, C.L. (1990) FASEB J. 4, 2460-2468

174. Jacob, F.(1982) The Possible and the Actual, Pantheon Books, New York

175. Raz, A., and Lotan, R. (1987) Cancer Metastasis Rev. 6, 433-452

176. Mandal, D.K., and Brewer, C.F. (1992) Biochemistry 31, 8465-8472

177. Hsu, D.K., Zuberi, R.I., and Liu, F.-T. (1992) J. Biol. Chem. 267, 14167-14174

178. Levi, G., Tarrab-Hazdai, R., and Teichberg, V.I. (1983) Eur. J. Immunol. 13, 500-505

179. Offner, H., Gelnik, B., Bringman, T.S., Casentini-Borocs, D., Nedwin, G.E., and Vandenbark, A.A. (1990) J. Neuroimmunol. 28, 177-184

180. Kajikawa, T., Nakajima, Y., Hirabayashi, J., Kasai, K., and Yamazaki, M. (1986) Life Sci. 39, 1177-1181

181. Yamaoka, K., Ohno, S., Kawasaki, H., and Suzuki, K. (1991) Biochem. Biophys. Res. Commun. 179, 272-279

182. Goldstone, S.D., and Lavin, M.F. (1991) Biochem. Biophys. Res. Commun. 178, 746-750

183. Ruggiero-Lopez, D., Louisot, P., and Martin, A. (1992) Biochem. Biophys. Res. Commun. 185, 617-623

184. Ackerman, S.J., Corrette, S.E., Rosenberg, H.F., Bennett, J.C., Mastrianni, D.M., Nicholson-Weller, A., Weller, P.F., Chin, D.T., and Tennen, D.G. (1993) J. Immunol. 150, 456-468

185. Imanishi, K. (1984) J. Social Biol. Struct. 7, 357-368

186. Rubinsky, B., Coger, R., Ewart, K.V., and Fletcher, G.L. (1992) Nature 360, 113-114

187. Hu, C., Lee, E.Y., Hewitt, J.E., Baenziger, J.U., Mu, J.-Z. DeSchryver-Kecshkemeti, K., and Alpers, D.H. (1991) Gastroenterology 101, $1477-1487$

188. Wood, W.B. (1988) The Nematode Caenorhabditis elegans. Cold Spring Harbor Laboratory, New York

Recived on February 1, 1993; accepted on June 1, 1993 